\title{
The Impacts of the Covid-19 Coronavirus Pandemic on International Environmental Protection
}

\author{
Empire Hechime Nyekwere \\ Lecturer, Department of Public Law, Faculty of Law, Redeemer's University, Osun State, Nigeria. Ph.D. \\ Research Candidate (Nnamdi Azikiwe University, Anambra State, Nigeria); LL.M. (University of Ibadan, Oyo \\ State, Nigeria); BL. (Lagos); LL.B. (Obafemi Awolowo University, Osun State, Nigeria).
}

\begin{abstract}
The COVID-19 Pandemic, first reported in Wuhan-the capital of Hubei Province of China in December 2019, is a human tragedy that is currently affecting millions of people around the globe. Presently, about 215 countries have reported cases of COVID-19. As of September 23, 2020, case growth, according to the Worldometer, has accelerated to $31,850,036$ cases, with 976,559 deaths and 23,449,907 recoveries. The World Health Organization (WHO), on January 30, 2020, announced COVID-19 as a pandemic and listed it as a public health emergency of global concern. It indicated with certainty that the COVID-19 epidemic would extend to every part of the world and noted that all individuals, businesses, and governments could change the disease's trajectory. On March 24, 2020 , noting that the COVID-19 Pandemic is progressively spreading and its impacts upon human health and the economy escalating daily, the United Nations Environment Programme (UNEP) urged governments to take urgent actions to minimize possible secondary impacts upon the global environment. However, a cursory survey of the effects of the COVID-19 Pandemic on the world would show that it has already impacted international environmental protection in multidimensional ways. Thus, this paper focuses on the impacts of the COVID-19 coronavirus pandemic on international environmental protection.
\end{abstract}

Keywords: COVID-19 Pandemic, international environmental protection (IEP), positive impacts of COVID-19 on IEP, negative impacts of COVID-19 on IEP, balancing economic growth with environmental protection.

DOI: $10.7176 / \mathrm{JLPG} / 101-12$

Publication date:September $30^{\text {th }} 2020$

\section{INTRODUCTION}

The global situation with the spread of the COVID-19 Pandemic is evolving rapidly and is a huge concern to the international community. ${ }^{1}$ The outbreak of the COVID-19 Pandemic globally has disturbed the political, social, economic, religious, and financial structures of the world. Both evolving economies and the world's leading economies, such as the US, China, UK, Germany, France, Italy, Japan, and several others, have been negatively affected by the coronavirus pandemic. ${ }^{2}$ The UN's Framework for the Immediate Socio-Economic Response to the COVID-19 crisis warns that the COVID-19 Pandemic is far over a health crisis affecting societies and economies at their core. ${ }^{3}$ In other words, the impacts of the COVID-19 Pandemic go beyond health, touching upon a wide range of human activities ${ }^{4}$ and increasing global challenges. ${ }^{5}$ For example, the World Bank recently estimates that $40-60$ million persons will be plunged into extreme poverty in 2020 , lossing about three years of progress in poverty reduction. ${ }^{6}$

As the health and human toll rises, global damage is already evident. ${ }^{7}$ Border closures, travel restrictions, social distancing, and other emergency necessities have profoundly affected businesses worldwide. ${ }^{8}$ Several people have lost their jobs or seen their incomes cut due to the COVID-19 pandemic crisis. Unemployment rates have increased across significant economies as a result. ${ }^{9}$ The International Labour Organization predicts that

${ }^{1}$ GEF, COVID-19 Updates from the GEF Partnership (Global Environment Facility, 14 May 2020) <https:// www.thegef.org/news/covid-19updates-gef-partnership > accessed 15 May 2020; The Environmental Impact of COVID-19 <https://www.msn.com/en-gb/news/world/theenvironm...> accessed 18 May 2020; See João Hrotkó and Tolu Oyekan, COVID 19-Challenges and Opportunities for Nigerian Leaders, Presentation at the American Business Council (ABC) Membership Meeting (Boston Consulting Group, 31 March 2020 ) p. 3.

2 Irfan Mahar, 'Impact of Covid 19 on Global Economy Structure' Modern Diplomacy Newsletter (Online, 22 April 2020 ) $<$ https://moderndiplomacy.eu/2020/04/22/impact-of-covid-19-on-global-economy-structure/> accessed 8 August 2020.

${ }^{3}$ UNDP, COVID-19: Socio-Economic Impact < https://www.undp.org/content/undp/en/home/coronavirus/socio-economic-impact-of-covid19.html $>$ accessed 9 August 2020.

${ }^{4}$ Par Harvey Parafina, Fighting Covid and Climate Change: What does this mean for Climate Science? <https://www.h eidi.news/genevasolutions/fighting-covid-and-climate-change-what-does-this-mean-for-climate-science> accessed July 2020.

${ }^{5}$ UNDP, COVID-19: Socio-Economic Impact, supra note 3 .

${ }^{6}$ María Mendiluce and Jose Siri, The COVID-19 Recovery can be the Vaccine for Climate Change (World Economic Forum, 9 June 2020).

${ }^{7}$ See The Global Economic Outlook during the COVID-19 Pandemic: A Changed World (The World Bank, 8 June 2020) $<$ https://www.worldbank.org/en/news/feature/2020/06/08/the-global-economic-outlook-during-the-covid-19-pandemic-a-changed-world > accessed 9 August 2020.

${ }^{8}$ Rebecca Hoare and Juliette King, Managing Environmental Risk during the COVID-19 Crisis: A Queensland Perspective $<$ https://www.nortonrosefulbright.com/en/knowledge/publications/e2387267/managing...> accessed 15 May 2020.

${ }^{9}$ Lora Jones and Daniele Palumbo and David Brown, 'Coronavirus: A Visual Guide to the Economic Impact' BBC News (London, 30 June 2020); See António Guterres, The World of Work cannot and should not look the same after this Crisis (United Nations, 2020). 
COVID-19 could cost the equivalent of 305 million full-time jobs, whereas 1.6 billion workers in the informal economy could suffer "massive damage" to their livelihoods. According to the United Nations Conference on Trade and Development (UNCTAD), international trade values fell 3\% in the first quarter of 2020, with further declines expected in the following quarters. ${ }^{1}$

The temporary closure of some businesses and operations slowing down for many makes the consequences of the COVID-19 Pandemic worse for the global economy than the ones following the Great Financial Crisis in 2007-2008. ${ }^{2}$ The COVID-19 Pandemic is indeed a catastrophe taking an enormous toll on humanity, disrupting lives and livelihoods. The magnitude and harshness of the COVID-19 Pandemic are unprecedented. Everything has been affected. The way we live and interact with each other, how we work and communicate, how we move around, and travel. All facet of our lives has been impacted. ${ }^{3}$ The COVID-19 Pandemic is indeed the biggest threat in living memory to health and wellbeing, social welfare, and the global economy. ${ }^{4}$

Without urgent socio-economic responses, universal suffering will escalate, jeopardizing lives and livelihoods for years to come. ${ }^{5}$ Thus, Nations of the world are making efforts at different levels-international, regional, national, and local levels to ensure that the spread and devastating impacts of the COVID-19 Pandemic is contained. Whereas the immediate focal point (priority) has been on managing impacts on people and the economy (saving lives and incomes), it is essential to be aware that the COVID-19 Pandemic and the global response to it, has impacted both positively and negatively on international environmental protection. ${ }^{6}$ A cursory study of the COVID-19 Pandemic on the world would confirm that it has already impacted international environmental protection in several ways.

\section{POSITIVE IMPACTS OF THE COVID-19 PANDEMIC ON INTERNATIONAL ENVIRONMENTAL PROTECTION}

\subsection{Reduction in Global Greenhouse Gas (GHG) Emissions}

The public health stay at home measures enforced by several countries to contain the spread of the COVID-19 Pandemic has contributed to a decline in global greenhouse emissions. ${ }^{7}$ Because industries, transport networks, and businesses have closed down, it has brought a sudden drop in carbon dioxide (CO2) emissions. In Europe, satellite images from the European Space Agency (ESA) have shown nitrogen dioxide (NO2) emissions dropping over northern Italy, Spain, the United Kingdom, Los Angeles, and San Francisco. ${ }^{8}$ Similar satellite images have been shown around the world, and there have been recent reports that the ozone layer is even repairing itself at unprecedented levels. ${ }^{9}$

There are diverse reasons that account for these changes we have seen. Take transportation, for example. According to researchers at Lund University, transport accounts for about $23 \%$ of global carbon dioxide (CO2) emissions. They also explained that flying (aviation) and driving make up $11 \%$ and $72 \%$ of transportations'

$<$ https://www.un.org/en/coronavirus/world-work-cannot-and-should-not-look-same-after-crisis > accessed 8 August 2020; See 'New UN Report offers Blueprint for Greener, more Resilient World of Work' UN News (Online, 19 June 2020). <https://news.un.org/en/> accessed 8 June 2020.

${ }^{1}$ See Robert Hamwey, Coronavirus Vaccine won't protect us against Climate Change (United Nations Conference on Trade and Development (UNCTAD), 2020) <https://unctad.org/en/pages/newsdetails.aspx?Orig inalVersionI D=2384> accessed 7 August 2020.

${ }^{2}$ Emmanuel Jurczenko, What is the Impact of COVID-19 on Global Economy? <https://www.hospitalitynet. org/opinion/4098208.html> accessed 2 August 2020.

${ }^{3}$ Hamwey, supra note 11 .

${ }^{4}$ Editorials: Covid-19: How a Virus is Turning the World Upside Down' BMJ 2020; $369<$ https://www.bmj.co m/content/369/bmj.m1336> accessed 10 August 2020.

${ }^{5}$ UNDP, COVID-19: Socio-Economic Impact, supra note 3.

${ }^{6}$ See Hoare and King, supra note 9; See Angel Gurría, Tackling Coronavirus (COVID-19): Contributing to a Global Effort $<$ www.oecd.org >coronavirus $>$ accessed 17 May 2020

${ }^{7}$ Mariecor Agravante, COVID-19 and its Effects on the Environment $<$ https://inhabitat.com/covid-19-and-its-effects-on-the-environment $>$ accessed 30 May 2020; See Mikayla Mace-Arizona, COVID-19 is a Global Experiment for the Environment <www.futurity.org>covid-19pandemic-environ ment-2...> accessed 14 May 2020; See Lenzen M, and others, 'Global Socio-Economic Losses and Environmental Gains from the Coronavirus Pandemic' [2020] (15)(7) PLoS ONE, e0235654. <https://doi.org/10.1371/jou rnal.pone.0235654> accessed 2 August 2020; See Le Quéré C, and others, 'Temporary Reduction in Daily Global CO2 Emissions During the COVID-19 Forced Confinement' [2020] (10) Nature Climate Change, 647-653.

${ }^{8}$ Martha Henriques, 'Will COVD-19Have a Lasting Impact on the Environment?' $B B C$ News (London, 27March2020);Ali P. Y. and Yoshifumi, M. and Yasuaki, H. 'COVID-19 and Surface Water Quality: Improved Lake Water Quality during the Lockdown, [2020] (731) Science of the Total Environment, 1-8:2; Lucas Fontes, COVID-19 vs. Environment-What is the Impact of Coronavirus on Nature? $<$ Medium.com $>$ covid19-vs environment-what-is-the-i...> accessed 18 May 2020; SeeJacinta Bowler, 'New Evidence Shows How COVID-19 has Affected Global Air Pollution' Science Alert (Online, 17 March 2020) <https://www.sciencealert.com/ here-s-what-covid-19-is-doing-to-our-pollution-levels> accessed 14 May 2020; See Stephanie Bedo, COVID-19 Coronavirus: Environmental Benefits of Coronavirus Pandemic Across the World $<$ www.nzherald.co.nz $>$ world $>$ news $>$ article $>$ accessed 18 May 2020; See ESP, Coronavirus Lockdown Leading to Drop in Pollution Across Europe (The European Space Agency, 27 March 2020); See UNECE, Declines in Air Pollution Due to COVID-19 Lockdown Show Need for Comprehensive Emission Reduction Strategies (United Nations Economic Commission for Europe, 2020).

${ }^{9}$ Andrew Heffernan, Opinion-Why COVID-19 Will Not be Good for the Environment <www.e-ir.info> 2020/04 / 30>why-covid-19-willnot-b...> accessed 15 May 2020. 
greenhouse gas emissions, respectively. ${ }^{1}$ These emissions have dropped in countries where public health measures, such as keeping people in their homes, have cut unnecessary travel. ${ }^{2}$ The Copernicus Atmosphere Monitoring Service has found a significant drop in nitrous oxides and fine particulate matter (PM) emission produced by traffic (especially diesel vehicles) and the burning of wood, peat, and coal. The reduction took out the equivalent of almost 1.5 billion tonnes of $\mathrm{CO} 2$ in China and could curb global emissions from air travel by 11 to 19 percent, according to Bloomberg Intelligence. ${ }^{3}$

Additionally, it is well-known that seagoing ships contribute significantly to total greenhouse gas emissions from the transportation sector. Approximately 3.1 percent of global carbon dioxide (CO2) emissions and $10 \%$ of global sulphur dioxide emissions (SO2) can be attributed to the maritime industry. ${ }^{4}$ High sulphur fuels dominate in international shipping. Three major environmental and health problems are of concern concerning maritime sulphur emissions: climate interference, ocean acidification, and health problems due to local air pollution. With decreased global trade and hence, international shipping, we will likely see more reductions in these emissions over the coming months. ${ }^{5}$

The International Energy Agency reported that the global energy demand and use are set to fall by $6 \%$ this 2020 due to the COVID-19 Pandemic. This will result in the cut of carbon dioxide $\left(\mathrm{CO}_{2}\right)$ emissions by 1600 million tonnes this 2020, which is around 5.5 percent of total worldwide emissions in $2019 .{ }^{6}$ To put the preceding view into perspective, that is equal to taking 3.46 billion passenger vehicles away from the roads for one year as calculated, making use of the Environmental Protection Agency Greenhouse Gas Equivalencies Calculator. ${ }^{7}$ This report is in line with recent global happenings. For example, as factories and businesses temporarily closed down, in addition to other restrictions to combat the COVID-19 Pandemic, China's coal use dropped by $40 \%$ at the country's six largest power plants. There was a significant reduction in the consumption of fossil fuels, and emissions fell $25 \%$ compared to the previous quarter of $2019,{ }^{8}$ according to the Centre of Research for Energy and Clean Air (CREA). ${ }^{9}$

More so, global carbon dioxide (CO2) emissions are set to fall nearly $8 \%$ this year to their lowest level ever since 2010, the most significant drop ever recorded in history. ${ }^{10}$ Simultaneously, the US crude oil prices dipped below zero in April 2020, before regaining slightly. This may reduce pollution from fossil fuels and provide new and innovative energy transition modalities. ${ }^{11}$ That means the COVID-19 Pandemic crisis is so far triggering the largest ever annual fall in carbon dioxide (CO2) emissions in 2020, more than during any previous economic crisis or period of war. ${ }^{12}$

\subsection{Reduction In Global Air Pollution And Improvement Of Earth's Air Quality}

With the entire population in several countries ordered to stay at home, factories, schools, and businesses limited their activities. Road traffic dwindled to a minimum as fewer cars are on the roads. The maritime industry reduced its activities as boats are on anchor. Airlines reduced scheduled flights by $60 \%$ to $95 \%$ as most airplanes are in the hangar. Whereas these developments have caused significant economic and social shocks as international production, consumption, and employment levels have fallen suddenly. They have also been linked with substantial reductions in global air pollution. Consequently, air quality levels in the world's leading cities have

\footnotetext{
1 Tawana Andrew, 'Behind the Forecast: COVID-19's Environmental Impact' Wave3 News (Online, 3 April 2020) $<$ https://www.wave3.com/2020/04/03/behind-forecast-covid-s-environmental-impact/> accessed 15 May 2020.

${ }^{2}$ Henriques, supranote 17.

${ }^{3}$ Kevin O'Sullivan, 'Benign Impact of Covid-19 on Air Quality and Carbon Emissions' The Irish Times (Online, 28 March 2020) $<$ https://www.irishtimes.com/news/environment/benign-impact-of-covid-19-on-air-quality-and-carbon-emissions-14213930> accessed 16 May 2020.

${ }^{4}$ Steve J.B, Alison, M. and Benno, T. 'Sink or Swim: The COVID-19 Impact on the Environmental Health, Fish Levels and Illicit Maritime Activity' [2020] (April 22) Bahaviour \& Social Sciences <https://socialscien ces.nature.com/users/376755-beno-torgler/posts/66544-sink-orswim...> accessed 15 May 2020; See Eyring, V. and others, 'Transport Impacts on Atmosphere and Climate: Shipping' [2010] (44)(1) Atmospheric Environment, 47-71; See Smith, S.J. and others., 'Anthropogenic Sulfur Dioxide Emissions: 1850-2005' [2011] (11)(1) Atmospheric Chemistry and Physics, 1101-1116.

${ }^{5}$ Steve, Alison and Benno, ibid; See Mest, T. and others, 'The Doubtful Environmental Benefit of Reduced Maximum Sulfur Limit in International Shipping Fuel' [2013] (47)(1) Environmental Science \& Technology, 98-101.

${ }^{6}$ Anna Brach, Opinion/COVID-19 Crisis Shouldn't Undermine the Need for Environmental Action-Quite the Opposite, (Geneva Centre for Security Policy (GCSP), 8 May 2020) <www.gcsp.ch>global-insight $>$ covid-19 crisis-shouldn...> accessed 15 May 2020 ; Simon Evans, Analysis: Coronavirus Set to Cause Largest Ever Annual Fall in CO2 Emissions (Carbon Brief, 9 April 2020) $<$ https://www.carbonbrief.org/analysis-coronavirus-set-to-cause-largest-ever-annual-fall-in-co2-emissions $>\quad$ accessed $20 \quad$ May 2020; Agravante, supra note 16.

${ }^{7}$ What Impact will COVID-19 have on the Environment? <www.science.org.au $>$ curious $>$ what-impact-will-cov id...> accessed 16 May 2020.

${ }^{8}$ Andrew, supra note 19 .

${ }^{9}$ Fontes, supra note 17 .

${ }^{10}$ Brach, supra note 24; See Peter, M. and Laura, A. and Dagomar, D., Experts Ponder Effect of COVID-19 on Future of Sustainability and the Environment (Georgetown University, 15 April 2020) <https://www.georgeto wn.edu/news/experts-ponder-effect-of-covid-19-on-future-of...> accessed 16 May 2020

${ }^{11}$ Brach, ibid.

${ }^{12}$ Agravante, supra note 16.
} 
improved significantly. Air quality improved primarily because of a decrease in factory, road, and air traffic emissions of carbon dioxide (CO2), nitrogen oxides (NOx), and related ozone (O3) formation and particulate matter (PM). ${ }^{1}$

Around the world, levels of various harmful atmospheric pollutants like $\mathrm{NO}_{2}$ (nitrogen dioxide), $\mathrm{CO}_{2}$ (carbon monoxide), $\mathrm{SO}_{2}$ (sulphur dioxide), and $\mathrm{PM}_{2.5}$ (small particulate matter) have dropped-at least, while shutdowns continue. In Europe, Rome experienced 26-35 percent average nitrogen dioxide concentrations lower than for the same period in 2019. Madrid experienced a 51 percent reduction in average nitrogen dioxide concentrations. London and Edinburgh have experienced a drop in nitrogen dioxide levels by up to 60 percent compared to the same period last year. Notoriously polluted cities such as Delhi, Bangkok, São Paulo, and Bogotá are also reportedly enjoying clearer skies and better air quality. ${ }^{2}$ Cities in the United States, such as Los Angeles and New York, have observed considerable improvements in air quality. ${ }^{3}$

According to the Chinese Ministry of Ecology and Environment, the number of days with "good quality air" increased by $11.4 \%$ compared with the same time last year in 337 cities across China. ${ }^{4}$ National Aeronautics and Space Administration (NASA) satellite images showed a dramatic drop in air pollution across Europe and China. They revealed a significant reduction in nitrogen dioxide concentrations-coinciding with the strict quarantine measures. ${ }^{5}$ There are various stories of dramatic improvement in air quality in other parts of the world since the stay at home lockdown measures was introduced. ${ }^{6}$ The 2020 Air Quality Index ${ }^{7}$ has shown that cities with previously high levels of small particulate matter have observed a remarkable fall in pollution since enforcing lockdowns, $44 \%$ in Wuhan, $54 \%$ in Seoul, and $60 \%$ in New Delhi. ${ }^{8}$ In a report collated by air quality information and tech company IQAir, 9 out of 10 major global cities that imposed COVID-19 shutdowns measured small particulate matter reductions of 25-60 percent compared to the same period last year. ${ }^{9}$

Improvement in Earth's air quality due to a decrease in global air pollution has impacted positively on human health. For example, compared with this period last year, air pollution levels in New York have dropped by almost

${ }^{1}$ Robert Hamwey, Environmental Impacts of Coronavirus Crisis, Challenges Ahead (United Nations Conference on Trade and Development (UNCTAD), 20 April 2020) <https://unctad.org/en/pages/newsdetails.a spx?OriginalVersionID=2333> accessed 14 May 2020; See NASA Probes Environment, COVID-19 Impacts, Possible Links <https://www.nasa.gov/feature/nasa-probes-environment-covid-19-impactspossible-links> accessed 17 May 2020; See Greg Odogwu, 'The Impact of COVID-19 on the Environment' The Punch Newspaper (Nigeria, 30 April 2020)

${ }^{2}$ What Impact will COVID-19 have on the Environment?, supra note 25; See Will COVID-19 Lockdowns Generate Public Support for Climate Change Mitigation? <https://thewire.in/environment/covid-19-lockdown-public-support-climate-change-mitigation>accessed 17 May 2020; See Michelle Ruiz, An Unintended Consequence of COVID-19 Shutdowns? Blue Skies and Cleaner Air $<$ https://www.yahoo.com/lifestyle/uni nten ded...> accessed 17 May 2020; See Miranda Jackson-Nudelman, It's Dangerous to View COVID-19 as a Solution to Environmental Issues $<$ https://www.bupipedream.com/opinions/116474/its-dangerous-to-view-covid -19-as-a...> accessed 17 May 2020; See Puspa, A. and Kurnya, R. and Yose, R. D., 'COVID-19 Opportunity to Enhance our Environmental Commitments' The Jakarta Post (Online, May 5, 2020) $<$ https://www.thejakartapo st.com/academia/2020/05/05/covid-19-opportunity-to-enhance-our-environmental-commitments.html $>$ accessed 5 June 2020; Renee Cho, What Can We Learn from COVID-19 to Help with Climate Change?' (Earth Institute: Columbia University, 26 March 2020).

${ }^{3}$ What Impact will COVID-19 have on the Environment?, supra note 25; See Will COVID-19 Lockdowns Generate Public Support for Climate Change Mitigation?, supra note 25; Heather Thomas, 'Travel Restrictions could Cost U.S. \$10.3 Billion in Chinese Visitor Spending' Reuters (Online, 4 February 2020) <https://www. reuters.com/article/us-china-health-tourism-idUSKBN1ZY25R> accessed 5 June 2020.

${ }^{4}$ Henriques, supra note 17; See Qiang, W. and Min, Su. 'A Preliminary Assessment of the Impact of COVID-19 on Environment-A Case Study of China' [2020] (728) Science of the Total Environment, 1-10:7; See Lauri Myllyvirta, Analysis: Coronavirus Temporarily reduced China's CO2 by a Quarter (Carbon Brief, 19 February 2020) <https://www.carbonbrief.org/analysis-coronavirus-has-temporarily-reduced-chinas-co2emissions-by-a-quarter> accessed 10 June 2020; See Lauri Myllyvirta, Why Does the Smog Strike Beijing Even When the City is Closed Down? (Centre for Research on Energy and Clean Air, 25 February 2020).

5 Stephanie Bedo, COVID-19 Coronavirus: Environmental Benefits of Coronavirus Pandemic across the World $<$ https://www.nzherald.co.nz/world/news/article.cfm?c id=28objectid=12322740 > accessed 18 May 2020; Jeremy Wilks and John-Paul Ging, 'Coronavirus and Climate: How much Impact is the Current Lockdown Really having on our Environment?' Euro News (Online, 28 April 2020) <https://www.euronews.com/2020/04/ 13/covid-19-and-climate-how-much-impact-is-the-current-lockdown-really-having-on-ourenvironm> accessed 10 June 2020; See Fei, L. 'Abrupt Decline in Tropospheric Nitrogen Dioxide over China after the Outbreak of COVID19’ [2020] (6)(28) Science Advances <https://advances.sciencemag.org/content/6/28/eabc2992> accessed 10 July 2020.

${ }^{6}$ Brach, supra note 24; World Economic Forum, The Deadly Link between COVID-19 and Air Pollution <https: //www.weforum.org/agenda/2020/04/the-deadly...> accessed 30 May 2020; See Environmental Regulation and COVID-19-An Overview $<$ www.williamfry.com >news $>$ article $>2020 / 04 / 09>$ env... $>$ Accessed 18 May 2020; Peter and Laura and Dagomar, supra note 28.

${ }^{7} \mathrm{The} \mathrm{AQI}$ is an Index for Reporting Daily Air Quality. It tells you how Clean or Polluted your Air is, and what Associated Health Effects might be a Concern for you. The AQI focuses on Health Effects you may Experience within a few Hours or Days after Breathing Polluted Air. See Air Quality Index (AQI) Basis-USEPA Server <https://cfpub.epa.gov/airnow/index.cfm?action=aqibasics.aqi > accessed 30 May 2020.

${ }^{8}$ Isabelle Gerretsen, How Air Pollution Exacerbates Covid-19 <www.bbc.com-fiture >aticle 2020042 how-air-...> accessed 15 May 2020; See Beth Gardiner, Pollution made COVID-19 Worse. Now, Lockdowns are Clearing the Air (National Geographic, 8 April 2020) $<$ https://www.nationalgeographic.com/science/2020/04/pollution-made-the-pandemic-worse-but-lockdowns-clean-the-sky/> accessed 20 June 2020.

${ }^{9}$ What Impact will COVID-19 have on the Environment?, supra note 25. 
$50 \%$ due to measures to control the COVID-19, ${ }^{1}$ and 11,000 air pollution-related deaths were avoided. ${ }^{2}$ Fortyeight thousand people die annually in France because of atmospheric pollution, and more than one million in China. Scientists estimate the United States death toll from air pollution at more than 100,000 per year. ${ }^{3}$ However, according to calculations carried out by Earth Science Assistant Professor Marshall Burke at Stanford University, the fall in air pollution due to the industrial shutdowns is expected to have saved between 53,000 to 77,000 lives in China alone. ${ }^{4}$

Although exposure to outdoor air pollution does not damage our health as speedily as infectious diseases like COVID-19 might, WHO estimates that it accounts for 4.2 million premature deaths every year by escalating the risk of cardiovascular and respiratory disease, cancer, and adverse birth outcomes. A study from Harvard University links exposure to air pollution with higher mortality in COVID-19 cases. ${ }^{5}$ Air pollution is estimated to be accountable for seven to eight million deaths per year, and fossil fuels are mostly to blame. ${ }^{6}$

\subsection{Increased Global Campaign Against Illegal Wildlife Harvesting And Trade (Wildlife Crime)}

The COVID-19 Pandemic has resulted in an increased global campaign against illegal wildlife harvesting and trade. ${ }^{7}$ Wildlife crime looked at generally is believed to worth about $\$ 200$ billion a year, and it is having a damaging effect on the local communities, national economies, ecosystems as well as public health. ${ }^{8}$ Illegal wildlife trade is the fourth largest transnational crime after drugs, weapons, and human trafficking. The Pandemic, which has sent countries into lockdown and wiped billions from economies, has refocused attention on the illicit harvesting and trade of wild animals. ${ }^{9}$ The harvest and sale of wild animals (human exploitation of wildlife) is a continuous threat to the survival of several species, in addition to infrequently posing a hazard to human society through viruses, as in the present case. A blend of two connected phenomena is believed to have caused the COVID-19 Pandemic. First, is the growing complex and potentially harmful interaction between humans and wildlife through illegal wildlife hunting, harvesting, and trade. Secondly, the ever-present and accelerated movement of people and goods across borders-one of the features of modern globalization. Whereas the former set of factors enabled the transmission of the COVID-19 virus from animals to humans, the latter has allowed its subsequent spread to pandemic proportions. ${ }^{10}$

Pandemics such as COVID-19 are the result of humanity's exploitation of wildlife. The illegal and unsustainable wildlife trade is one of the driving forces behind the increasing number of diseases leaping from wildlife to humans. ${ }^{11}$ It is on record that every year, poachers take an enormous 38 million animals from the wilds of Brazil to meet up the worldwide demand for illegal wildlife. Largely are birds, destined to become caged pets

\footnotetext{
${ }^{1}$ Henriques, supra note 17; Advisory on Disclosure of Material Impact of COVID-19 Pandemic on Listed Entities under SEBI (Listing Obligations and Disclosure Requirements) Regulations, $2015<$ COVID-19-Page 3-BlogsClub.in.https://blogsclub.in/tag/covid19/page/3/> accessed 20 May 2020.

${ }^{2}$ Brach, supra note 24; See Lauri Myllyvirta, 11,000 Air Pollution-Related Deaths avoided in Europe as Coal, Oil Consumption Plummet, (Centre for Research on Energy and Clean Air, 30 April 2020).

${ }^{3}$ Jeff McMahon, Coronavirus Lockdown May Save More Lives by Preventing Pollution than by Preventing Infection' Forbes (Online, 11 March 2020) <https://www.forbes.com/sites/jeffmcmahon/2020/03/11/coronavir us-lockdown-may-save-more-lives-from-pollution-andclimate-than-from-virus/> accessed 20 June 2020.

${ }^{4}$ What Impact will COVID-19 have on the Environment?, supra note 25; See Gerretsen, supra note 38; See Peter and Laura and Dagomar, supra note 28 .

${ }^{5}$ What Impact will COVID-19 have on the Environment?, ibid; See Gerretsen, ibid; See Peter and Laura and Dagomar, ibid.

${ }^{6}$ O'Sullivan, supra note 21; See Ryan Schmelz, 'Environmental Impact of COVID-19' Spectrum News 1 (Online, 6 April 2020) <https://spectrumnews1.com/oh/columbus/news/2020/04/06/environmental-impact-of-covid-19> accessed 20 July 2020; Chris Mooney, 'Climate Change Poses a Severe Risk to Global Health, says New Report' The Washington Post (Online, 23 June 2015) $<$ https://www.washingtonpost.com/news/energy-env ironment/wp/2015/06/22/climate-change-poses-a-potentially-catastrophic-risk-toglobal-health-says-new-report /> accessed 15 May 2020; See Robin Pomeroy, Air pollution kills 7 Million People a Year - and Probably makes COVID-19 more Deadly: This Week's World Vs Virus Podcast (World Economic Forum, 25 June 2020).

${ }^{7}$ Malavika Vyawahare, 'As Covid-19 Pandemic Deepens, Global Wildlife Treaty faces Scrutiny' EcoBusiness News (Online, 18 May 2020) $<$ https://www.eco-business.com/news/as-covid-19-pandemic-deepens-global-wild life-treaty-faces-scrutiny/> 6 June 2020.

${ }^{8}$ John Scanlon (Interview with Vanessa Kortekaas), Coronavirus: New Wildlife Trade Regime Needed to Avoid Next Pandemic' Financial Times (Online, 9 July 2020) <https://www.ft. com/video/e5912dea-7a61-4e 05-9115-cfa2a727d9a3> accessed 6 August 2020.

${ }^{9}$ Fiona Gordon, 'Covid-19 and New Zealand's Role in the Global Illegal Wildlife Trade' [2020] (Commentary) Journal of African Elephants: Spotlighting the Plight of Africa's Elephant <https://africanelep hantjournal.com/ covid-19-and-new-zealands-role-in-the-global-illegalwildlife-trade/> accessed 30 July 2020.

${ }^{10}$ Implications of COVID-19 for the Environment and Sustainability, Institute for Global Environmental Strategies (IGES) Position Paper, 14 May 2020,p. $4<$ https://www.iges.or.jp/en/news/20200514> accessed 30 May 2020.

${ }^{11}$ Damian Carrington, 'Pandemics Result from Destruction of Nature, Say UN and WHO' The Guardian (International Edition, 17 June 2020); See Ivonne Higuero, How Regulation of Endangered Wildlife Trade can Prevent the Next Pandemic $<$ https://www.scmp.com/comment/opinion/article/3089832/how-regulation-endan gered-wildlife-trade-can-prevent-next-pandemic $>$ accessed 30 July 2020; See Linda Givetash, 'Preventing the Next Pandemic will Cost \$22.2 Billion a Year, Scientists Say' NBC News (Online, 23 July $2020)<$ https://www. nbcnews.com/news/world/preventing-next-pandemic-will-cost-22-2-billion-year-scientists-n1234688> accessed 30 July 2020; See Marco Lambertini and Elizabeth Maruma Mrema and Maria Neira, 'Coronavirus is a warning to us to Mend our Broken Relationship with Nature' The Guardian (International Edition, 17 June 2020).
} 
for owners in Rio de Janeiro or Sydney or Madrid or New York. ${ }^{1}$ Biodiversity (all biological diversity from ecosystems, to species, to genes) is declining faster than at any time in human history. We clear forests and remove habitat, getting wild animals nearer to human settlements. And we hunt and sell wildlife, usually endangered, escalating the risk of disease transmission from animals to humans. ${ }^{2}$

We have known for some time the devastating consequences of wildlife crime on local communities, national economies, fuelled by corruption, etc. But COVID-19 Pandemic has raised the attention of the global community to these deficiencies and recognized the public health risk connected with poorly-regulated, unregulated, and illegal trade in wildlife and unmitigated destruction of wild places. The COVID-19 Pandemic has lifted the attention and focus of governments, citizens, corporations, etc. to demand a much better system for regulating wildlife trade, dealing with wildlife crime, and protecting wild places. ${ }^{3}$

According to Yan Xiang, professor of virology at the University of Texas Health Science Centre, "We're getting closer and closer to wild animals, and that brings us into contact with these viruses." 4 To put this into perception, the majority (three out of every four) of new infectious diseases in humans come from animals-from wildlife and from the livestock we keep in ever-larger quantities. ${ }^{5}$ Research shows that $60 \%$ of all known infectious diseases in humans and $75 \%$ of all emerging infectious diseases come from wildlife (i.e., zoonotictransmitted from animals to humans). $17 \%$ of all contagious diseases are spread by animal vectors causing more than 700,000 annual deaths. As we move into natural habitats and exploit more wildlife, contact between humans and disease-carrying species increases. Diseases from farm animals (livestock) and other animals are infecting humans at a high rate than ever, resulting in at least 2.5 billion illnesses and 2.7 million human deaths per year, with more and increasing instances in developing countries. ${ }^{6}$

COVID-19 Pandemic has highlighted the catastrophic impacts of illegal and unregulated wildlife trade and consumption. ${ }^{7}$ Conservation of wildlife may keep their pathogens in check, preventing zoonotic spill-over, and ultimately benefiting humans, too. ${ }^{8}$ As the health disaster keeps impacting human life internationally, it also underscores the pressing and urgent need to act to improve ecological security, reinforce the protection of wildlife and regulation of wildlife trade. ${ }^{9}$ In other words, the global community must act to tackle the origins of zoonotic diseases, as well as the illegal, unregulated, and underregulated trade and consumption of wildlife that is believed to have led to the COVID-19 Pandemic and is generally believed to be the cause of HIV, Ebola, SARS, and MERS. Thus, the COVID-19 epidemic may yet prove to be a crucial moment in the attempts to address the illegal wildlife harvesting and trade-because the cost of disease emergence and spill-over from wildlife will be significantly higher than the economic gain of our exploitation of the environment. ${ }^{10}$

\footnotetext{
${ }^{1}$ Claudia S. de Windt, 'Environmental Rule of Law: Pandemics Now and the Next Time in the Americas' (15, April 2020) p. 4 $<$ https://www.iucn.org/sites/dev/files/content/documents/2020/pandemicsnowandnexttimefin alpaper.pdf > accessed 6 August 2020; See Susan Daugherty, Fighting for Brazil's Stolen Species (National Geographic, 2014) $<\mathrm{https}$ ://www.nationalgeographic.com/news/2014/12/141227juliana-machado-ferreira-ani mal-trafficking-birds-brazil/> accessed 30 July 2020; See What does more Environmental Damage: Eating Meat from the Wild or a Factory Farm? <https:/www.theguardian.com/environment/2020/may/26/ban-on-bushmeat-after-covid-19-but-what-ifalternative-is-factory-farming? > accessed 31 July 2020.

${ }^{2}$ Fiona Armstrong, Anthony Capon and Ro McFarlance, Coronavirus is a Wake-up Call: Our War with the Environment is Leading to Pandemics $<$ https://theconversation.com/coronavirus-is-a-wake... > accessed 17 May 2020;

${ }^{3}$ John E. Scanlon, 'What is the Impact of the Coronavirus Pandemic? Global Experts Answer the Big Questions -'Coronavirus: The Big Question' Financial Times (Online, 28 July 2020) <https://www.ft.com/video/e5912dea -7a61-4e05-9115-cfa2a727d9a3>accessed 6 August 2020.

${ }^{4}$ Charli Shield, Coronavirus Pandemic Linked to Destruction of Wildlife and World's Ecosystems <https:// www.dw.com/en/coronaviruspandemic-linked...> accessed 17 May 2020.

5 Armstrong, Capon and McFarlance, supra note 52; Fiona Armstrong, COVID-19 and Climate Change Connected $<$ News,LaTrobe....https://www.latrobe.edu.au/news/articles/2020/opinion/covid-19-and-climate-cha nge-connected $>$ accessed 17 May 2020; Alayna Demartini, Are Animals Vulnerable to COVID-19? <Phys.org. https://phys.org/news/2020-03-animals-vulnerable-covid-.html> accessed 5 June 2020.

${ }^{6}$ See Grace D, and others, Mapping of Poverty and Likely Zoonoses Hotspots. Zoonoses Project 4. Report to the UK Department for International Development. (Nairobi, Kenya: International Livestock Research Institute (ILRI), 2012); See Protect the Environment, Prevent Pandemics, 'Nature is Sending Us a Clear Message' UN News (Online, 5 June 2020) $<$ https://news.un.org/en/story/2020/06/1065692> accesses 31 July 2020; See Inger Andersen and John Rockstrom, COVID-19 is a Symptom of a Bigger Problem: Our Planet's Ailing Health <https://time.com/5848681/covid-19-world-environment-day/> accessed 31 July 2020; See Neela Banerjee, 'Q\&A: A Harvard Expert on Environment and Health Discusses Possible Ties Between COVID and Climate' Inside Climate News (Online, 12 March 2020).

${ }^{7}$ Dilys Roe, Despite COVID-19, Using Wild Species May Still be the Best Way to Save Them (International Institute for Environment and Development (IIED), I April 2020) < https://www.iied.org/despite-covid-19-using-wild-species-may-still-be-best-way-save-them > accessed 20 July 2020.

${ }^{8}$ Amy, Y.V. and Gabriel, Z.L. and Maria, A.M.S., How Deforestation helps Deadly Viruses Jump from Animals to Humans, The Conversation (Online, 25 June 2020) <https://theconversation.com/how-deforestation-helps-deadly-viruses-jump-from-animals-to-humans-139645> accessed 20 July 2020.

${ }^{9}$ Imogen Braddick, 'Wuhan Officially Bans Eating Wild Animals in Crackdown on Illegal Wildlife Trade' Evening Standard (Online, 20 May $2020)<$ https://www.standard.co.uk/news/world/wuhan-ban-eating-wild-ani mals-coronavirus-bats-a4446491.html > accessed 15 June 2020.

${ }^{10}$ Simon Evans, 'Coronavirus has Finally made us Recognise the Illegal Wildlife Trade is a Public Health Issue' The Conversation (Online, 17 March 2020) <https://theconversation.com/coronavirus-has-finally-made-us-recognise-the-illegal-wildlife-trade-is-a-public-health-issue-
} $133673>$ accessed 20 June 2020 
Consequently, many voices have begun calling for the shutting down of high-risk "wet markets" where living and dead wildlife and domestic animals of diverse species and origins come together, conditions that make a perfect environment for coronaviruses and other wildlife-borne diseases to spill over to humans. Some, including Elizabeth Maruma Mrema, the United Nations' biodiversity chief, campaigns for much broader action, for example, the end to all wildlife trade and consumption, and to ban all wildlife markets ${ }^{1}$ - a call that is beginning to yield positive results. ${ }^{2}$ China, for example, has heeded to the call by placing a ban on illegal wildlife harvesting and trade (China recently closed these markets and the business that supplies them). ${ }^{3}$ More specifically, on February 24, 2020, China's top legislature, the National People's Congress (NPC), announced a ban on the hunting, husbandry, trade, and use of wild animals as food to safeguard people's lives and health, a step welcomed as 'timely, necessary and critical' by World Wide Fund for Nature (WWF). ${ }^{4}$ Further, Authorities in Wuhan, the epicentre of the coronavirus outbreak, have officially banned eating, hunting, and breeding of wild animals within the city limits except for "scientific research, population regulation, monitoring of epidemic diseases and other special circumstances," and Wuhan has been declared "a wildlife sanctuary."5 The ban on the capture, trade, and sale of live wild animals for food in China is believed to lead to reduced hunting pressure and the recovery of populations in the wild? ${ }^{6}$

Also, many environmental conservation experts have called on the Convention on International Trade in Endangered Species of Wild Fauna and Flora or CITES to live up to expectations and its mandates of dealing with international trade in wildlife and conservation concerns. These calls are coming on the basis that CITES is an international environmental treaty that regulates the global trade in some of the world's most threatened species, with the power to ban it when needed. ${ }^{7}$ CITES aim is to keep the international trade of wild plants and animals legal, sustainable, and traceable. Its Parties make decisions to make sure that international trade of valuable wild species of plants and animals does not endanger their survival in the wild. ${ }^{8}$

\subsection{Sustainable Lifestyle Behavioural Change Barrier Broken and Global Awareness Of The Possibility To Reverse Some Of The Dangerous Trends Of Global Warming}

The COVID-19 pandemic crisis has created massive behavioural change in a way that environmental policies have struggled to do. For example, the COVID-19 Pandemic seems to have done more to lower greenhouse gas emissions than just about any environmental-climate policy over the past two decades. We are already beginning to experience reductions in emissions of carbon dioxide, the most significant greenhouse gas, owing to the economic disruption caused by the COVID-19 Pandemic. ${ }^{9}$ People have taken several appealing radical measures in recent weeks because of the situation at hand. While these changes have been intense, they demonstrate that the world can make adjustments-adjustments that can reduce negative impacts on our climate. ${ }^{10}$

The COVID-19 Pandemic has changed our lives in ways we never imagined: shutting schools, offices, shops, factories, grounding airlines, and closing borders. Yet it has, in addition, shown that we have the willpower and the capability to face down dangers; that all of us - families, businesses, and governments have the determination to act drastically and resolutely when the moment calls for it. The coronavirus has moved with frightening speed, and we have responded with urgency, taking the necessary action. We have not faltered to suspend "normal life" because we understand that it is required. Companies all over the world are showing how they can take action to protect people and the most vulnerable. And governments are promptly designing some of the most significant economic incentive packages ever seen in peacetime, to make sure that the damage to economies, companies, and people is minimized and the chances of a strong recovery maximised. The COVID-19 Pandemic has created an international awareness of the need not to return to business as usual and lock in previous practices, pollution, spending, and infrastructure that will cause additional harm to the very economies, communities, and people that

\footnotetext{
${ }^{1}$ Dan Ashe and John E. Scanlon, A Crucial Step Toward Preventing Wildlife-Related Pandemics: We Need to Reform the Convention on International Trade in Endangered Species of Wild Fauna and Flora (CITES)' (Scientific America, 15 June 2020) $<$ https://www.scientificamerican.com/article/a-crucial-step-toward-preven ting-wildlife-related-pandemics/> accessed 30 July 2020. ${ }^{2}$ Shield, supra note 54 .

${ }^{3}$ See Richard, T.C. Impacts of the Coronavirus Pandemic on Biodiversity Conservation (Biological Conservation, 8 April 2020) $<$ https://pdxscholar.library.pdx.edu/cgi/viewcontent.cgi?article=1018context=polis ci.fac $>$ accessed 17 May 2020.

4 WWF urges China to set a Global Example as it Mulls Revision of the Wildlife Protection Law <https://wwf. panda.org/wwf news/press releases/?363735/WWF-urges-China-to-set-a-global-example-as-it-mulls-revision-of-the-Wildlife-ProtectionLaw $>$ accessed 31 July 2020 .

${ }^{5}$ Braddick, supra note 59 .

${ }^{6}$ Richard, supra note 63.

${ }^{7}$ Vyawahare, supra note 46

${ }^{8}$ See Interview with Ivonne Higuero: There are no Winners in the Illegal Trade in Wildlife (United Nations Environment Programme, 5 May 2020) < https://www.unenvironment.org/news-and-stories/story/there-are-no-winners-illegal-trade-wildlife > accessed 1 August 2020.

9 Alyssa Hurst, Q\&A: Has COVID-19 Shifted the Momentum of Climate Change? (University of Denver, 22 April 2020) $<$ https://www.du.edu/news/qa-has-covid-19-shifted-momentum-climate-change $>$ accessed 17 May 2020.

${ }^{10}$ Geoff Bansen, What is COVID-19's Effect on the Environment? <www.news 12.com>story>what-is-covid19s-effect-on-th...> accessed 17 May 2020.
} 
the incentive packages seek out to support. ${ }^{1}$

The response to the COVID-19 Pandemic has confirmed what can be done differently, thus, revealing exciting insights on adaptation. The COVID-19 Pandemic has compelled us to adjust our behaviour and adopt new everyday practices in significant ways, not all of which will permanently reverse after restrictions are lifted. New techniques, such as the mass use of online interaction and communication (remote working), are flourishing. ${ }^{2}$ More consumer trading and purchasing have moved online; cities are trying-out with converting streets to make room for cycling and walking, and international travel has virtually ceased-although for the time being. These and other developments will not persist unabated, but they will leave their mark on people's lives and our post-COVID-19 pandemic world in unpredictable ways. ${ }^{3}$ In the future, we may see less needless interstate and international travel after acknowledging success with remote online conferences, meetings, and even court hearings. Through this, we have already overcome an essential barrier to behaviour change. We can take advantage of this shift. ${ }^{4}$

The COVID-19 Pandemic has confirmed that countries can take a common stance against a threat to our collective wellbeing. We have already had almost three decades to control climate change. After over twenty-five years of climate negotiations, frameworks, and agreements, we have made only a little progress towards this objective. As an international society, we appear willing to accept that fighting the climate crisis requires too much sacrifice-at a global, local, and personal level. Hopefully, our response to the COVID-19 Pandemic has opened our eyes to what is possible, and what matters. Appreciating our successes in the fight against the COVID-19 Pandemic can provide insight into how we can confront not only threats to our health but also assaults on the health of the Earth, the source of all life. Combating the COVID-19 Pandemic obligated every one of us to play our part, alter our habits and daily schedules, and make individual sacrifices. ${ }^{5}$ Acceptance of the necessity to make sacrifices and accept restraints for both the general good and individual wellbeing could help increase understanding of the huge shifts in regulation and behaviour that are needed to address the climate change crisis. ${ }^{6}$ If we can convince ourselves to do alike in the fight against the climate change crisis, we will ultimately see real progress. ${ }^{7}$

The outcome of the COVID-19 Pandemic can bring about sustained behavioural changes amongst individuals. ${ }^{8}$ For instance, business flying has stopped meetings from happening. Still, people have found ways to work with video conferencing and other cheap technology, forcing businesses to question whether their staffs need to fly as much in the future. ${ }^{9}$ A research carried out by Satoshi Fujii at Kyoto University in Japan established that when a motorway is closed, people who own private cars are constrained to make use of public transit. According to the study, the same thing occurred when the road reopened; owners of private vehicles who had previously been dedicated drivers are inclined to travel more regularly by public transport. So, throughout this unprecedented period of COVID-19 Pandemic, habits that are coincidentally good for the climate might be travelling less or, perhaps, reduction in food waste in various households as we experience shortages due to hoarding. ${ }^{10}$

According to Christiana Figueres, former executive secretary of the United Nations Framework Convention on Climate Change (UNFCCC), the Covid-19 Pandemic has let loosed humanity's instinct to change itself in the face of a widespread threat, and it can assist us in doing the alike to create a liveable planet for future generations. ${ }^{11}$ One response to the coronavirus epidemic that has drawn varied reactions from climate scientists is the manner that several communities have taken giant steps to protect one another from the health crisis. The swiftness and degree of the response have given some prospect that rapid action could as well be taken on climate change if the

\footnotetext{
${ }^{1}$ María Mendiluce, 'How We Can All Come Back Better-and Greener-After COVID-19' The Telegraph, (Online, 21 April 2020) $<$ https://www.telegraph.co.uk/business/how-to-be-green/earth-day-covid-19/> accessed 20 May 2020.

${ }^{2}$ Laura Schuijers, COVID-19 is an Opportunity to Reset our Environmental Future, (University of Melbourne, 18 April 2020); Amandine Orsini, Lessons Learnt from Coronavirus and Global Environmental Challenges $<$ https: //blog.oup.com/2020/04/lessons-learnt-from... $>$ accessed 17 May 2020

${ }^{3}$ María Mendiluce and Jose Siri, The COVID-19 Recovery can be the Vaccine for Climate Change (World Economic Forum, 9 June 2020).

${ }^{4}$ Schuijers, supra note 72; See COVID-19: Four Sustainable Development Goals that help Future-Proof Global Recovery (United Nations Environment Programme (UNEP), 26 May 2020) < https://www.unenviron ment.org/ news-and-stories/story/covid-19-four-sustainabledevelopment-goals-help-future-proof-global $>$ accessed 9 August 2020; See Arthur Lyon Dahl, Does the Pandemic have a Silver Lining? (International Environment Forum, 19 March 2020)

${ }^{5}$ Hamwey, supra note 11 .

${ }^{6}$ Andrew Norton, Coronavirus and Climate Change are Two Crises that Need Humanity to Unite (International Institute for Environment and development, 13 March 2020).

${ }^{7}$ Hamwey, supra note 11

${ }^{8}$ Paul Omorogbe, 'COVID-19 Pandemic and Effect on Climate' Nigerian Tribune (Nigeria, 7 April 2020).

${ }^{9}$ Fiona Harvey, 'Financial help for Airlines 'should come with Strict Climate Conditions' The Guardian (International Edition, 1 April 2020). ${ }^{10}$ Omorogbe, supra note 78; See Emily Kasriel, A'Mass Experiment' for the Climate: Has the Pandemic helped Individuals and Leaders get any Closer to Tackling the Environmental Crisis? <https:/www.bbc.com/future/ article/20200624-has-covid-19-brought-us-closer-tostopping-climate-change $>$ accessed August 2020; See Leo Murray (Interview with Carbon Brief Staff), Coronavirus: What could Lifestyle Changes Mean for Tackling Climate Change? (Carbon Brief, 31 March 2020).

${ }^{11}$ Christiana Figueres (Interview with Carbon Brief Staff), Coronavirus: What could Lifestyle Changes Mean for Tackling Climate Change? (Carbon Brief, 31 March 2020); See Open Letter to Global Leaders-A Healthy Planet for Healthy People-Call to Action from the Planetary Emergency Partnership: Emerging from the Planetary Emergency and partnering between People and Nature $<$ https://clubofrome.org/impacthubs/climate-emergency/open-letter-to-global-leaders-a-healthy-planet-for-healthy-people/> accessed 10 August 2020.
} 
threat it poses was urgently treated. ${ }^{1}$

Government responses to climate breakdown and the challenges of poverty and inequality must be changed permanently after the COVID pandemic has been tackled, leading scientists have advised, as the actions taken to contain the spread of the virus have revealed what measures are possible in an emergency. The COVID-19 crisis has exposed what governments can do and shone a fresh light on the motivation for previous policies and their outcomes, according to Sir Michael Marmot-professor of epidemiology and public health at University College London, and chair of the commission of the social determinants of health at the World Health Organisation. The speed with which the government had acted showed that the response to an emergency, such as climate change, could be swift and decisive. But the climate crisis has been regarded as a "slow-burn" problem and had not elicited such a response. But, COVID-19 Pandemic exposes that we can do things differently by urgently tackling the climate change crisis and must not go back to the status quo ante. ${ }^{2}$

According to the Fifth Assessment Report of the Intergovernmental Panel on Climate Change, human activities over the past 50 years had warmed the Earth. These "activities" are mostly industrial activities upon which we depend. The panel is very confident that principal greenhouse gases produced as a result of human activities (nitrous oxide, methane, and carbon dioxide) are the source of the increase in the Earth's ambient air and ocean temperatures documented during the past half-century. ${ }^{3}$ However, the COVID-19 Pandemic demonstrates to humanity, without a reasonable doubt, that it is possible to slow down or still undo several of these dangerous tendencies of global warming. Humanity has made known that it can be very innovative in dealing with lifethreatening challenges. It is by getting together and addressing those challenges as a global community. ${ }^{4}$ The emissions of nitrous oxide, methane, carbon dioxide, and other pollutants have led to a temporary drop from their pre-COVID-19 pandemic levels. This emissions reduction has persuaded some persons to hope that our global society may be able to decrease greenhouse gas emissions significantly over the long term in other to tackle and mitigate climate change-the biggest threat to our existence..$^{5}$

\section{NEGATIVE IMPACTS OF THE COVID-19 PANDEMIC ON INTERNATIONAL ENVIRONMENTAL PROTECTION}

\subsection{Delays In Global Efforts For Environmental Action}

The COVID-19 Pandemic is likely to delay global efforts for environmental action, as it is undoubtedly distracting the high-level policy consideration required in 2020. This year was believed to be a transformational year for international environmental law. The schedule of intergovernmental meetings was packed. ${ }^{6}$ Not less than eight major United Nations Laws were supposed to be agreed on this $2020 .^{7}$ Given the continual uncertainties arising from the ongoing COVID-19 Pandemic, together with those linked to restrictions on travel and the assembling of large physical gatherings, key environmental negotiations initially scheduled to take place this year have been postponed. Thus, the COVID-19 Pandemic has shed significant uncertainties about the holding of these essential environmental talks by postponing them and risks delaying action and losing momentum. ${ }^{8}$

The postponed international environmental negotiations include:

1. The Intergovernmental Conference on Marine Biodiversity of Areas Beyond National Jurisdiction. The Fourth Session of the Intergovernmental Conference on an international legally binding instrument under the United Nations Convention on the Law of the Sea on the conservation and sustainable use of marine biological diversity of areas beyond national jurisdiction was postponed by the General Assembly decision 74/543 of March 11, 2020, to the earliest possible available date to be decided by the General Assembly. ${ }^{9}$ A decision to adopt a significant new treaty on marine biodiversity to regulate ocean biodiversity in areas beyond national jurisdiction was expected to be taken at this Conference. ${ }^{10}$

\footnotetext{
${ }^{1}$ Henriques, supra note 17.

${ }^{2}$ Fiona Harvey, 'Tackle Climate Crisis and Poverty with Zeal of COVID-19 Fight, Scientists Urge' The Guardian (International Edition, 28 March 2020); See Jamie Margolin, 'Politicians blew off Gen Z's Climate Goals. The Coronavirus shows we can act fast' The Washington Post (Online, 26 March 2020).

${ }^{3}$ Ali Fares, COVID-19 could be Once-in-a-Lifetime Opportunity to Fight Climate Change (Prairie View A\&M University, April 22, 2020); Life Adaptate Common Methodology for the Development of Sustainable Energy and Climate Action Plans in European Municipalities (Climate Adapt, 8 September 2018) <https://climate-adapt.eea.europa.eu/metadata/projects/common-methodology-for-the-development-ofsustainable-energy-and-c limate-action-plans-in-european-municipalities $>$ accessed 5 August 2020.

${ }^{4}$ Ali Fares, ibid.

${ }^{5}$ Hamwey, supra note 11 .

${ }^{6}$ Leslie-Anne Duvic-Paoli, COVID-19 Symposium: The COVID-19 Pandemic and the Limits of International Environmental Law $<$ opiniojuris.org/2020/03/30/covid-19-symposium-the...> accessed 10 May 2020.

See Nishan Degnarain, Ten Areas where COVID-19 Responses have Increased Environmental Risks <www. forbes.com $>$ sites $>$ nishandegnarain $>2020 / 04 / 16>$ accessed 14 May 2020; See Jamison Ervin, Applying the Hard Lessons of Coronavirus to the Biodiversity Crisis (United Nations Environment Programme, 27 March 2020)

${ }^{8}$ Duvic-Paoli, supra note 87.

9 Intergovernmental Conference on Marine Biodiversity of Areas Beyond National Jurisdiction (United Nations, 2020) $<$ https://www.un.org/bbnj/> accessed 12 August 2020

${ }^{10}$ Degnarain, supra note 88 .
} 
2. The implementation of the Paris Agreement that was to be concluded in December at a critical United Nations Framework Convention on Climate Change (UNFCCC) Climate Conference of Parties (COP) 26 in Glasgow, Scotland, in November expected to raise climate ambition. However, the Bureau of the Conference of the Parties to the UNFCCC, with the UK and its Italian partners, agreed on new dates for the COP26 UN climate conference, which will now hold between 1 and 12 November 2021 in Glasgow. ${ }^{1}$

3. The International Union for Conservation of Nature (IUCN) World Conservation Congress held every four years to appraise international conservation efforts and scheduled for 11-19 June 2020, has been decided by the IUCN and the French government to now take place from 7-15 January 2021 in Marseilles. ${ }^{2}$

4. As agreed by the Bureau, the fifteenth meeting of the Parties to the Convention on Biological Diversity (CBD) (COP-15), initially scheduled for October 2020 to agree on a post-2020 global biodiversity framework and set the next ten years' biodiversity targets by the UN CBD will now be held on 17-30 May 2021, in the Chinese city of Kunming. ${ }^{3}$

5. The 2020 United Nations Ocean Conference scheduled to take place from 2-6 June 2020 in Lisbon, Portugal, has been postponed by decision 74/548 adopted by the General Assembly on Monday, April 13, 2020. Cohosts of the Conference Kenya and Portugal, in consultation with the General Assembly, will decide on future dates for the Conference, including timelines for the preparatory process. ${ }^{4}$

6. The German government, in consultation with the Fifth International Conference on Chemicals Management (ICCM5) President and IP Co-Chairs, has announced the necessity of postponing the ICCM5, that is, the Strategic Approach to International Chemicals Management (SAICM), from 5 to October 9, 2020, to 5-9 July 2021 in Bonn, Germany. ${ }^{5}$

7. On July 9, 2020, the Bureau of the Open-ended Working Group (OEWG) of the Basel Convention agreed to hold an up to 4-day face to face meeting of the OEWG-12 in March 2021, in Nairobi, Kenya, back to back with the Fifth Session of the United Nations Environment Assembly (UNEA-5), subject to the availability of resources and a positive improvement of the coronavirus disease (COVID-19) situation. ${ }^{6}$

8. The Convention on International Trade in Endangered Species of Wild Fauna and Flora (CITES) Standing Committee has recommended to the CITES Secretariat that the $31^{\text {st }}$ meeting of the CITES Animals Committee (AC31) and the 25 $5^{\text {th }}$ meeting of the Plants Committee (PC25) should be postponed until 2021. The 73rd meeting of the CITES Standing Committee was planned to hold from 5 to October 9 in Geneva, but the session will not be held on those dates. Though, as was the case for the meetings of the Animals and Plants Committees, the uncertainty caused by the COVID-19 Pandemic has led the CITES Secretariat and the Members of the Standing Committee to talk about the circumstances in which the meeting should be held. ${ }^{7}$

\footnotetext{
${ }^{1}$ New Dates for Major Environmental Negotiations: United Nations Framework Convention on Climate Change (UNFCCC) (Geneva Environment Network, 30 July 2020) <https://www.genevaenvironmentnetwork.org/resou rces/up dates/news-dates-for-major-environmentalnegotiations/> accessed 6 August 2020; Press Release: New Dates Agreed for COP26 United Nations Climate Change Conference $<$ https://www.gov.uk/government/news/ new-dates-agreed-for-cop26-united-nations-climate-change-conference> accessed 6 August 2020; UN, Key COP26 Climate Summit Postponed to 'Safeguard Lives' UN News (Online, 2 April 2020) <https://news.un.org/ en/story /2020/04/1060902> accessed 7 August 2020; COP26 is Postponed because of Coronavirus Pandemic (World Meteorological Organization, $2020)<$ https://public. wmo.int/en/media/news/cop26-postponed-because-of-coronavirus-pandemic > accessed 7 August 2020; Fiona Harvey, 'We Must Use this Time Well': Climate Experts Hopeful After COP26 Delay' The Guardian (International Edition, 2 April 2020); Kiley Price, If Coronavirus Halts Climate Convenings, 'We Must Find other Avenues for Progress' Conservation International (Online, 11 March 2020 ). ${ }^{2}$ See IUCN World Conservation Congress, Information on the New Dates of the Conference (International Union for the Conservation of Nature, 2020) <https://www.iucncongress2020.org/newsroom/inform ation-new-dates-congress > accessed 6 August 2020.

${ }^{3}$ News Dates for Major Environmental Negotiations: Convention on Biodiversity Diversity (CBD) (Geneva Environment Network, 30 July 2020) <https://www.genevaenvironmentnetwork.org/resources/updates/news-dates-for-major-environmental-negotiations/> accessed 6 August 2020; Press Release: New Dates Announced for UN Biodiversity Convention Meetings Crucial to Development of the Post-2020 Global Biodiversity Framework <https://www.cbd.int/doc/press/2020/pr-2020-07-16-sbstta-sbi-en.pdf > accessed 6 August 2020.

${ }^{4}$ UN Ocean Conference, Lisbon, Portugal (United Nations, 2020) $<$ https://www.un.org/en/conferences/ocean $2020>$ accessed 12 August 2020 ; Degnarain, supra note 88; See Joel Makower, Biodiversity, Pandemics and the Circle of Life (GreenBiz Group, 20 April 2020); See Smriti Mallapathy, The Biodiversity Leader who is Fighting for Nature Amid a Pandemic <https://www.nature.com/articles/d41586-020-01947-9> accessed 1 August 2020.

${ }^{5}$ News Dates for Major Environmental Negotiations: Strategic Approach to International Chemicals Management (SAICM) (Geneva Environment Network, 30 July 2020) https://www.genevaenvironmentnetwor k.org/resources/updates/news-dates-for-major-environmentalnegotiations/> accessed 6 August 2020; Message to Stakeholders: Recent Updates on SAICM <http://www.saicm.org/Portals/12/Docu ments/Messages/2020-04-09_SAICM-message-to-stakeholders.pdf $>$ accessed 6 August 2020.

${ }^{6}$ News Dates for Major Environmental Negotiations: Basel, Rotterdam and Stockholm Conventions (BRS MEAs) (Geneva Environment Network, 30 July 2020) <https://www.genevaenvironmentnetwork.org/resources /updates/news-dates-for-major-environmental-negotiations/> $\begin{array}{llllll}\text { accessed } & 6 & \text { August } & 2020 ; & \text { Approach } & \text { for }\end{array}$ $<$ http://www.basel.int/TheConvention/OpenendedWorkingGroup(OEWG)/Meetings/OEWG12/Over review/tabid/8264/Default.aspx> accessed 6 August 2020.

${ }^{7}$ News Dates for Major Environmental Negotiations: Convention on International Trade in Endangered Species of Wild Fauna and Flora (CITES) (Geneva Environment Network, 30 July 2020) <https://www.genevaenvironm entnetwork.org/resources/updates/news-dates-formajor-environmental-negotiations/> accessed 6 August 2020; Announcement on the 73rd Meeting of the CITES Standing Committee $<$ https://cites.org/eng/Standing Com mittee Announcement CITES 16072020> accessed 6 August 2020.
} 
By postponing these environmental summits, the valuable political drive may be lost as priorities shift in the wake of COVID-19. Delays to these summits could permit disobedient countries to move the agenda toward COVID-19 health and economic recovery policies, and afar from environmental priorities. ${ }^{1}$ Also, in addressing the global COVID-19 Pandemic, international cooperation and coordination are crucial. The same goes for addressing environmental challenges. The year 2020 was intended to be the year of environmental action and bold decisions. As in the case of any international negotiations, side conversations are often critical to the results of such discussions. Yet several international environmental conferences that were to take place in 2020 have been postponed until 2021 or until further notice. ${ }^{2}$

For instance, the environmental agenda for 2020, the concluding year of the UN's Decade on Biodiversity, was set to conclude in October in Kunming, China, with the Convention on Biological Diversity's 15th Conference of Parties. Delegates from 196 countries scheduled to convene to finalize negotiations on an international biodiversity policy framework to replace the 2010 Aichi Biodiversity Targets expiring at the end of the year. Organizers are now taking into consideration a makeup date for the critical CBD summit sometime in the second quarter of 2021-precisely on 17-30 May 2021. Experts worry the world will lose vital time to turn around frightening tendencies in biodiversity loss and climate change. The resources apportioned to fight the COVID-19 Pandemic might mean fewer resources for biodiversity initiatives later on. The postponement comes at a significant time for biodiversity. Environmental degradation is increasing globally, and over a million species are at danger of extinction, according to the 2019 Report of the Intergovernmental Science-Policy Platform on Biodiversity and Ecosystem Services. According to Linda Krueger, senior policy adviser for the United States-based NGO, the Nature Conservancy, any delay is going to make the eventual solutions much tougher. ${ }^{3}$

\subsection{Relaxation Of Environmental Regulations And Enforcements}

The United Nations Special Rapporteur ${ }^{4}$ on human rights and the environment-David Boyd has cautioned and appealed that countries must not use the COVID-19 Pandemic as an excuse to weaken environmental protection and enforcement. This warning by the UN Special Rapporteur comes after several governments have announced that they are lowering environmental standards, suspending environmental monitoring requirements, reducing environmental enforcement, and restricting public participation or other related measures. ${ }^{5}$

Suspending environmental regulations and enforcement, according to David Boyd, are irrational, irresponsible, and jeopardize the rights of billions of people, particularly those who are already in danger to environmental damage as well as indigenous peoples, people living in poverty, elderly, women, minorities and children. ${ }^{6}$ The short-term decision to weaken or suspend environmental regulations and enforcements will make things even worse. ${ }^{7}$ Such policy decisions are prone to cause a speedy decline in the environment. They have adverse effects on a broad scope of human rights, comprising the rights to life, health, water, culture, and food, in addition to the right to live in a healthy environment. ${ }^{8}$ Instead, governments have to speed up efforts to achieve the 2030 Sustainable Development Goals since a healthy environment is an efficient means to prevent future pandemics and safeguard human rights. Given the universal environmental predicament that predates the COVID-19 Pandemic, States should intensify their endeavours to protect the environment, not step back. ${ }^{9}$ Examples of countries whose response to the COVID-19 Pandemic has been used as an excuse to relax their environmental standards, monitoring requirements, regulations, and enforcement are as discussed below:

3.2.1 United States Lowers Vehicle Emission Standards, Relaxes the Enforcement of Monitoring and Reporting Requirements of Environmental Protection for Companies, and Opens Up the Northeast Canyons and Seamounts Marine National Monument to Commercial Fishing

In the United States, President Trump's administration has announced two significant changes at the federal level. Firstly, fuel efficiency standards for new cars were drastically reduced. A rollback on the car emissions rules that were a central piece of US efforts to decrease greenhouse gas emissions could result in increased gasoline consumption by 80 billion tons, increasing carbon emissions in the atmosphere. The lowering of federal vehicle

\footnotetext{
${ }^{1}$ See Degnarian, supra note 88.

${ }^{2}$ Brach, supra note 24 .

${ }^{3}$ James Dinneen, 'COVID-19 Disrupts a Major Year for Biodiversity Policy and Planning' Mongabay News (Online, 3 April 2020) $<$ https://news.mongabay.com/2020/04/covid-19-disrupts-a-major-year-for-biodiversity-policy-and-planning/> accessed 16 May 2020; See ASEAN Centre for Biodiversity (ACB), World Wildlife Day: Taking a holistic approach in wildlife Conservation (ASEAN Centre for Biodiversity (ACB), 4 March 2020) <https://pia.gov.ph/news/articles/1035667> accessed 22 May 2020.

${ }^{4}$ Also referred to as an Independent Expert, Special Rapporteur Examine and Report Back to the Human Rights Council on a Specific Human Rights Theme or Country Situation.

${ }^{5}$ David Boyd, 'COVID-19 Environmental Roll Back 'Irrational and Irresponsible': Rights Expert' UN News (Online, 15 April 2020)

$<$ https://news.un.org/en/story/2020/04/1061772> accessed 20 May 2020.

${ }^{6} \mathrm{Ibid}$

${ }^{7}$ UN HRC, COVID-19: "Not an Excuse" to Roll Back Environmental Protection and Enforcement, UN Rights Expert Says

$<$ https://reliefweb.int/report/world/covid-19-not-excuse-roll-back-environmental...> accessed 16 May 2020.

${ }^{8}$ Boyd, supra note 103 .

${ }^{9} \mathrm{UN}$ HRC, COVID-19, supra note 105.
} 
emission standards, according to some, could lead to years of environmental regulatory uncertainty. ${ }^{1}$ In reaction, Greenpeace USA Senior Climate Campaigner Caroline Henderson said that by lowering fuel efficiency standards, the USA's current administration is condemning thousands of more people to die from air pollution. Rolling back fuel efficiency standards will amplify disease-causing particulate matter and aggravate the global climate emergency. ${ }^{2}$

Earthjustice Staff Attorney-Paul Cort, expressing disapproval of the fuel efficiency standards reduction, noted that amid a public health crisis, the Trump government is once again placing oil industry profits ahead of the American people. Weakening clean car standards will significantly increase air pollution and harm public health. Transportation, according to Cort, is the major source of carbon pollution in the US, and that this move undercuts one of the country's most vital tools to solve the climate crisis. ${ }^{3}$ The clean car standards, pronounced by the Obama government in 2012, intended to cut carbon pollution from new vehicles in half by 2025 . They were intended to generate about 650,000 jobs, save consumers about $\$ 50$ billion in 2030 , and decrease climate pollution by 280 million metric tons in $2030 .^{4}$

Secondly, the US Environmental Protection Agency (USEPA) is relaxing the enforcement of monitoring and reporting requirements of environmental protection for companies for an indefinite time, if the company can show a COVID-19 connected reason for non-compliance..$^{5}$ According to USEPA's top compliance official, Susan P. Bodine, the policy sets new guidelines for companies to monitor themselves for an undetermined period during the COVID-19 and noted that the USEPA would not issue fines for breaches of certain air, water, and hazardouswaste-reporting requirements. Companies are generally required to report when their factories discharge certain levels of pollution into the air or water. ${ }^{6}$ Disapproving this decision, Amnesty International is of the view that the Trump administration is cynically abusing this crisis to achieve its pre-COVID-19 goal of gutting US environmental regulations. It is hard to exaggerate the risk. The decision to indefinitely suspend the protections given by environmental laws will kill or compromise the health of large numbers of people. According to Amnesty, these impacts will be felt by everyone in the USA, but mainly by people already facing marginalization and discrimination, as well as those who live in regions surrounded by heavily polluting industrial facilities. USEPA enforcement of environmental laws saves hundreds of thousands of people from premature death every year, and millions more from preventable illnesses and sicknesses. This decision, in Amnesty's view, should be immediately revoked. ${ }^{7}$

Thirdly, President Donald Trump recently issued a proclamation that opens up the Northeast Canyons and Seamounts Marine National Monument to commercial fishing, risking the destruction of this sensitive and biologically crucial marine reserve by resource extraction activities, for example, bottom-scouring fishing. It is noteworthy that the Northeast Canyons and Seamounts Marine National Monument is a distinctive and remarkable ocean region off the coast of New England. Designated as a monument in 2016, it is the first significant marine national monument established in the US Atlantic Ocean. This protected region offers food, shelter, and nursery habitat to an amazing collection of marine life, as well as endangered whales, puffins, sea turtles, and uncommon deep-sea cold-water corals. The Northeast Canyons and Seamounts Marine National Monument protect 4,913 square miles of pristine ocean ecosystem-an area almost the size of Connecticut, covering 1.5 percent of US federal waters on the East Coast. The monument is a safe haven (refuge) for marine life and offers a defence for the Northwest Atlantic against the worst effects of climate change. The national monument designation is intended to protect the Northeast Canyons and Seamounts from commercial extractive activities, plus commercial fishing and oil and gas drilling.

${ }^{1}$ Degnarain, supra note 88; Daniel, W. and Luciana, T. C., How Covid-19 Could Impact the Climate Crisis $<$ www.hrw.org $>$ accessed 14 May 2020; Feike Sijbesma, 'United States: Pricing Carbon Will Help Us Better Deal with Climate Change' The Telegraph (Online, 20 May 2019) $<$ https://www.telegraph.co.uk/business/how-to-be-green/pricing-carbon-climate-change/> accessed 15 June 2020.

${ }^{2}$ Ryan Schleeter, Trump Exploits COVID-19 Crisis to Roll Back Auto Pollution Rules (Greenpeace, 31 March 2020); See Felix Horne, US Car Emissions Rollback Endanger People's Health: Cut to Environmental Standards Exacerbates Risks of COVID-19 (Human Rights Watch, 2 April 2020); Three Big Automakers Pushed For Rollbacks of Obama Era Fuel Efficiency Standards $<$ https:/earthmaven.io/planetwatch/climate-politics-policy/three-big-automakers-pushed-for-rollbacks-of-obama-era-fuel-efficiencystandards-lEWz13po-0 yacAf3ftWq0Q $>$ accessed 1 August 2020.

${ }^{3}$ Earthjustice Condemns Rollback of Federal Clean Cars Standards (Earthjustice, 31 March 2020).

4 Ibid; See The Trump Administration's Hazy Plans to Weaken Car Pollution Standards Won't Work. Here's Why $<$ https://earthjustice.org/features/clean-air-act-auto-emissions-waiver > accessed 16 August 2020

${ }^{5}$ Degnarain, supra note 88; Daniel and Luciana, supra note 108; Sijbesma, supra note 108.

${ }^{6}$ Lisa Friedman, 'E.P.A., Citing Coronavirus, Drastically Relaxes Rules for Polluters' The New York Times (Online, 14 April 2020) $<$ https:/www.nytimes.com/2020/03/26/climate/epa-coronavirus-pollution-rules.html > accessed 15 June 2020; See Rebecca Beitsch, EPA Suspends Enforcement of Environmental Laws Amid Coronavirus' The Hill (Online, 26 March 2020) <https://thehill.com/policy/energyenvironment/489753-epa-suspends-enforcement-of-environmental-laws-amid-coronavirus $>$ accessed 10 May 2020; See Patrice Simms, What EPA's 'Enforcement Discretion’ During COVID-19 Really Means (Earthjustice, 27 March 2020).

${ }^{7}$ Amnesty International, USA: Immediately Revoke COVID-19 Suspension of Environmental Protections (Amnesty International, 2 March 2020).

${ }^{8}$ Earthjustice Responds to Trump's Rollback of Northeast Canyons and Seamount National Marine Monument: President Trump Issues Order Opening Northeast Canyons \& Seamounts to Harmful Industrial Fishing <https://earthjustice.org/news/press/2020/earthjustice-responds-to- 
Kicking against the Presidential proclamation, Steve Mashuda, Earthjustice's Managing Attorney of its Oceans Program, frowned that amid two national crises over systemic racism and a pandemic that rages on, the president has decided to prioritize opening up a national monument to commercial fishing, whilst weakening core environmental laws that protect people and the environment. According to Mashuda, it is not clear if President Trump is aware of the irony of shredding protections for Northeast Canyons and Seamounts National Monument on World Environment Day and during National Oceans Month, however, it is nonetheless intensely disturbing he would try to do this at all. He noted the issue of tackling a global extinction crisis that impacts the whole web of life, and that the proclamation is an assault on an ocean refuge that numerous marine wildlife depend on. Claims that the fishing industry will benefit from this action, according to Mashuda, are grossly overstated, as was made obvious by government documents in 2017 . He stated further that they condemn this action and are looking at every tool they have to support the fight against it. ${ }^{1}$

3.2.2 Canada Suspends Its Reporting and Monitoring Requirements under Its Environmental Law Regime, and Removes the Requirements for Public Consultation on Environmental Issues

Governments in Canada have used the COVID-19 Pandemic crisis to curb environmental protections for communities and ecosystems. The province of Alberta is amongst the few provinces that recently suspended the reporting and monitoring requirements under its environmental law regime. ${ }^{2}$ For instance, Alberta suspended reporting requirements under numerous environmental acts, with the exception of drinking water facilities. Afterward, changes by the Alberta Energy Regulator removed several monitoring requirements for oil companies, including monitoring surface water, groundwater, and wildlife in tailings ponds. ${ }^{3}$ Lately, Alberta, in addition, opened to a large extent the Eastern Rocky Mountains and Foothills to open-pit coal mining without public consultation. This change will restrict public access to land to enjoy hiking, camping, and fishing. ${ }^{4}$ Further, the province of Ontario has removed the requirements for public consultation on environmental issues during the current state of emergency. Usually, projects that affect the environment have a 30-day consultation period. The consultation period allows the public, including scientists, to comment on proposed projects or policies, for instance, permits that could affect endangered species or the approval of mining projects.

\subsubsection{China Temporarily Suspends Environmental Standards for Small Businesses}

As China resumes its economy, the Chinese Ministry of Ecology and Environment announced in mid-March 2020 that it would momentarily suspend environmental standards for small businesses to hasten economic recovery. This has been condemned by key environmental groups such as the World Wild Fund for Nature (WWF). ${ }^{5}$ According to the Global Energy Monitor and the Centre for Research on Energy and Clean Air data, China's provinces approved an additional new coal-fired facility between January 1 and June 15, 2020, than for the period of 2018 and 2019 put together. As a significant emitter of the world's greenhouse gases, China's coal capacity surge risks pushing emissions beyond pre-COVID-19 Pandemic levels.

\subsubsection{Brazil Reduces Surveillance of Amazon Rainforest}

In March 2020, owing to the COVID-19 outbreak, the two environmental enforcement agencies of Brazil announced that it is cutting back on its enforcement responsibilities, such as protecting the Amazon from increasing deforestation. As a result, Brazil has seen an increase in illegal logging. That could lead to the release of enormous quantities of greenhouse gases stored in one of the world's most essential carbon sinks. ${ }^{6}$ Thus, fewer Government environmental enforcement officers are going into the Amazon, and environmental monitoring efforts have been scaled back. Indigenous populations, who usually defend the Amazon against illegal logging, miners, and wildfires, are retreating further into the forest to avoid the COVID-19 outbreak. Such surveillance had been adequate in the

\footnotetext{
trumps-rollback-of-marine-monume nt-in-midst-of-pandemic-and-nationwide-crisis-over?utm_source=twitter\&utm_medium=social> accessed 30 July 2020

${ }^{1}$ Ibid.

${ }^{2}$ Paula Lombardi, Canada: Impact of COVID-19 on Environmental Law < www.mondaq.com>operational-im pacts-and-strategy $>$ accessed 15 May 2020.

${ }^{3}$ James, E.P. and Brynn, D. and Gideon, M., 'Rolling Back Canadian Environmental Regulations during Coronavirus is Short-Sighted' The Conversation (Online, 14 June 2020) <https://theconversation.com/rolling-back-canadian-environmental-regulations-during-coronavirus-isshort-sighted-139636> accessed 10 June 2020.

${ }^{4}$ Ibid.

${ }^{5}$ Degnarain, supra note 88

${ }^{6}$ Daniel and Luciana, supra note 108; See Christoph Seidle Spiegel, Melting Permafrost: Scientists Warn of Dangers of Trapped Carbons $<$ https://abcnews.go.com/International/melting-permafrost-scientists-warn-dangers -trappedcarbon/story?id=18569156 $>$ accessed 5 June 2020; See Dooley, J.J., 'Carbon Dioxide Capture and Geologic Storage: A Core Element of a Global Energy Technology Strategy to Address Climate Change' A Technology Report from the Second Phase of the Global Energy Technology Strategy Program <https://www. epa.gov/sites/production/files/2015-05/documents/act 200702 battelle.pdf $>$ accessed 5 June 2020; See Mauricio Torres and Sue Branford, 'Brazil Opens 38,000 Square Miles of Indigenous Lands to Outsiders' Mongabay Series: Amazon Conservation' Mongabay News \& Inspiration from Nature's Frontline (Online, 8 May 2020) <https://news.mongabay.com/2020/05/brazil-opens-38000-square-miles-ofindigenous-lands-to-out siders/> accessed 30 July 2020.
} 
past in preventing illegal loggers and deforestation. ${ }^{1}$

\subsubsection{Colombia Venezuela, Madagascar, Malaysia, Indonesia, Tunisia, Cambodia, India, Kenya Etc Reduces their Forests Regions Monitoring}

Colombia, Venezuela, Madagascar, Malaysia, Indonesia, Tunisia, Cambodia, India, Kenya, etc. have been reported to have reduced or weakened their environmental surveillance and monitoring of their forest regions due to the COVID-19 Pandemic. For instance, lockdown measures in Colombia have drastically reduced the capacity of government and community rangers to protect wildlife. ${ }^{2}$ Ever since Colombia went into lockdown in late March, monitoring flights by the armed forces that generally circle the tropical rainforest regions have significantly reduced. ${ }^{3}$

\subsection{Global Increase In Poaching, Animal Trafficking, Illegal Logging, and Deforestation Due To Weakened Environmental Surveillance And Monitoring}

Environmental agencies have reported an increase in deforestation during lockdowns, as well as increases in wildlife poaching, animal trafficking, and illegal logging and mining worldwide, especially in Asia, Africa, and Latin America. ${ }^{4}$ Recently, National Geographic raised alarms on poaching proliferation in conservation reserves as rangers and keepers self-isolated. ${ }^{5}$ Also, Conservation International field offices recently reported that poaching and deforestation had escalated ever since COVID-19 Pandemic restrictions went into effect. ${ }^{6}$ The trends are frightening, environmental experts say, and could be difficult to reverse. ${ }^{7}$ The longer these illegal activities are left to increase in tropical forest regions, the difficult it will be to alter the damages to these ecosystems and rainforest communities. ${ }^{8}$

Reports show that Amazonian deforestation in Brazil has reached a nine-year high since the Pandemic began in 2019. ${ }^{9}$ The first case of coronavirus was confirmed in Brazil on February 28, 2020. Still, while most of the economy has since come to a halt as state and municipal government implement lockdown measures, deforestation has not. In April 2020, rainforest destruction increased 64\%, compared with the same month in 2019, according to Brazil's National Institute for Space Research (INPE). Between January 1, 2020, and May 30, 2020, rainforest destruction increased by 55\%, compared with the same time in 2019, clearing an area of 1,202 square kilometres (464 square miles). According to Ane Alencar, the science director of the Brazilian environmental organisation has noted that what they have seen with deforestation is that people are not afraid because they think the government is distracted with the COVID-19 health crisis and that they won't pay attention to them. He added that it is an opportunistic thing. ${ }^{10}$

According to Miguel Pacheco, natural resources and livelihoods coordinator with World Wide FundColombia, in Columbia, environmental authorities have reported an increase in illegal logging, wild animal trafficking, and poaching of large cats like Jaguars, pumas, and other endangered species since quarantine began. The Philippines has reported illicit logging and wildlife trafficking, and related reports have come from Venezuela and Madagascar. Alarms have as well been raised in Malaysia and Indonesia, which have the uppermost deforestation rates in South-East Asia. In contrast, in Ecuador, indigenous and afro-descendent communities have reported increased illegal mining in the Choco and Amazon rainforests. In Cambodia, India, and Kenya, there has been an alarming increase in poaching, deforestation, illegal logging, and mining. ${ }^{11}$ Kenya has reported rises in

\footnotetext{
${ }^{1}$ Shield, supra note 54; See Lucy Jordan and Ana Terra Attayde, As Deforestation Surges, Brazil Moves to Weaken Indigenous and Environmental Safeguards <https:/unearthed.greenpeace.org/2020/04/29/coronavirus-amazon-deforestation-bolsonaro-brazil-weakensindigenous-environmental-safeguards/> accessed 30 July 2020.

${ }^{2}$ See Marco Lambertini, The Coronavirus is not Good for Nature $<$ https://www.aljazeera.com/amp/indepth/op inion/coronavirus-good-nature200508120555480.html?_twitter_impression=true $>$ accessed 30 July 2020.

${ }^{3}$ Kimberley Brown, The Hidden Toll of Lockdown on Rainforests $<$ https://www.bbc.com/future/article/2020 0518-why-lockdown-is-harmingthe-amazon-rainforest?ocid=ww.social.link.twitter $>$ accessed 30 July 2020

${ }^{4}$ Kimberley Brown, ibid; Sebastian Troëng and Edward Barbier and Carlos Manuel Rodríguez, The COVID-19 Pandemic is Not a Break for Nature-Let's make sure there is One after the Crisis (World Economic Forum, 21 May 2020); See Charlie Gardner, Nature's Comeback? No, the Coronavirus Pandemic threatens the World's Wildlife (World Economic Forum, 16 April 2020).

5 Travindy, Environmental Impacts of COVID-19<https://www.travindy.com/2020/04/covid-19-and-its-effects -on-the-environment> accessed 18 May 2020

${ }^{6}$ See Kiley Price, Poaching, 'Deforestation Reportedly on the Rise since COVID-19 Lockdowns' (Conservation International, 30 April 2020$)$ $<$ https://www.conservation.org/blog/poaching-defores tation-reportedly-on-the-rise-since-covid-19-lockdowns $>$ accessed 15 July 2020; See Dina Fine Maron, Poaching threats Loom as Wildlife Safaris Put on Hold Due to COVID-19' (National Geographic, 10 April 2020) $<$ https://www.national geographic.com/animals/2020/04/wildlife-safaris-halted-for-covid-boost-poaching-threat/> accessed 10 July 2020.

${ }^{7}$ Brown, supra note 124 .

${ }^{8}$ Ibid.

${ }^{9}$ Price, supra note 127

${ }^{10}$ Brown, supra note 124

11 Degnarain, supra note 88; See Matt Simon, The Coronavirus Lockdown is a Threat for Many Animals, Not a Blessing $<$ https://www.wired.com/story/coronavirus-lockdown-conservation/> accessed 31 July 2020; See John E. Scanlon, 'Conservation Must not be a COVID Victim' Independent (UK, 13 May 2020); See \#COVID Crime Watch - No.10. - Wildlife Crime: Rise Or Fall? (Global Initiative Against International Organized Crime, 27 May 2020); Henry Holloway, 'Brazil becomes Second Country to Hit One Million
} 
bushmeat and ivory poaching, as well as an increase in charcoal production, which has been banned since 2018 .

In Tunisia, over two nights in early April 2020, a group of persons in the northwest area of Ain Draham illegally felled 400 trees, a species referred to as Algerian oak, which is in the United Nations listing of endangered species, the country's forestry agency noted. When the authorities arrested eight individuals a few days later, they made known the trees, some of which had been standing for over 300 years, had been turned into charcoal. An additional 1,000 trees - oak and fern - were cut down in the night in the same region in Ain Draham on April 8, 2020, according to National Guard spokesman Houssemeddine Jebabli. ${ }^{1}$ From the time when Tunisia went into lockdown on March 22, the forestry bureau has raised 200 legal cases for breaches against the forest code, comprising illegal logging, unauthorised construction, and hunting in forest areas. That is ten times the number of cases in the same period last year, according to Mohamed Boufaroua, the Ministry of Agriculture general director of forestry. Mohamed stated further that the curfew gives cover to illegal loggers with fewer people around to apprehend them in the act, and that they (illegal loggers) want to take advantage of this period of confinement. According to Tunisia's forestry agency data, Tunisia's oak forests covered 140,000 hectares (346,000 acres) in 1970. Of that, there were 10,000 hectares of Algerian oak trees. Today, the species is down to 8,350 hectares $(20,633$ acres $)$ out of 95,000 hectares of oak overall. Cutting down the Algerian oak is a criminal offence in Tunisia. ${ }^{2}$

While poaching incidents have become more frequent in these countries, evidence suggests that two main factors could be driving these trends. ${ }^{3}$ The first is that criminal groups and opportunistic actors involved in landgrabbing, deforestation, illegal mining, and wildlife poaching are expanding their activities, taking advantage of lockdown and diminished forest monitoring and weak enforcement efforts since governments are currently focused on COVID-19 Pandemic crisis instead of on conservation. The second is that individuals living in these rural areas are facing increased economic pressures and are compelled to depend more greatly on the environment for food and income. In some instances, such as Madagascar and Cambodia, there has been a sizeable urban-rural migration as individuals lose their jobs in the cities or go back home to be with their families for the period of quarantine, which has put additional pressure on local environments. ${ }^{4}$ According to Michael O'Brien-Onyeka, senior vicepresident of Conservation International's Africa Field Division, in Africa's rural areas, one driver of this surge is the problem people are facing in finding their next meal. During a lockdown, people cannot go to work, particularly those in the informal market-who depend on going out every single day to make ends meet and come back with some food. For example, the man in the rural area who takes out his motorcycle taxi to go out and pick passengers to make some money cannot do that anymore. ${ }^{5}$

\subsection{Impact On Environmental Nonprofits}

The role of environmental advocacy by environmental nonprofits (environmental non-governmental organizations $)^{6}$ has never been more critical, given the planetary crisis. ${ }^{7}$ According to Ed Henry, President, and CEO of the Doris Duke Charitable Foundation, the nonprofits sector is necessary to building a just and thriving society. At this moment, their work is more critical than ever. ${ }^{8}$ However, the near-global lockdown in response to the COVID-19 Pandemic represents a typical example of an unprecedented interruption of economies and financial

Coronavirus Cases after Infections Rose by 54,000 in Just One Day' The Sun (Online, 20 June 2020) <https://www.thesun. co.uk/new s/11910846/brazil-one-million-coronavirus-cases-second-country/> accessed 10 August 2020.

${ }^{1}$ Layli Foroudi, 'Under the Cover of Lockdown, Illegal Logging Surges in Tunisia' Thomson Reuters Foundation News (Online, 1 May 2020) $<$ https://news.trust.org/item/20200501041915-qph07/> accessed 30 July 2020.

${ }^{2}$ Ibid.

${ }^{3}$ Price, supra note 127; See Maron, supra note 127; Troeng and Barbier and Rodrigues, supra note 125.

${ }^{4}$ Troeng and Barbier and Rodrigues, ibid; Brown, supra note 124.

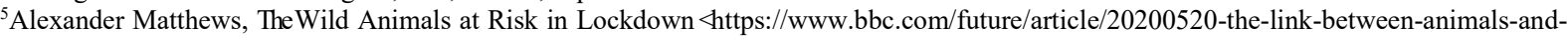
covid-19> accessed 31 July 2020.

${ }^{6}$ Some globally recognized environmental non-profits include: Sierra Club; National Audubon Society; World Wildlife Fund; Earth First Worldwide; Greenpeace; National Wildlife Federation; Natural Resources Defence Council (NRDC); Green America; World Business Council for Sustainable Development; Forest Stewardship Council; Rainforest Action Network; The Nature Conservancy; Environmental Defence Fund; Friends of the Earth (FOE); Worldwatch Institute; American Bird Conservancy; Intergovernmental Panel on Climate Change; Earth Policy Institute; Wildlife Conservation Society; Association of Environmental Professionals; National Geographic Society; Rocky Mountain Institute; Centre for Biological Diversity; National Parks Conservation Association. See Cyndi Meuchel, 25 Top Environmental Non-Profits [9 April 2014] <https://moneyminder.com /blog/top-environmental-non-profits/> accessed 18 May 2020; See Joanne Fritz, Top-Rated Nonprofits Protecting the Environment [5 March 2020] $<$ https://www.thebalancesmb.com/best-nonprofits-protecting-the-environment-in2018-417 7878> accessed 18 May 2020.

${ }^{7}$ UNEP and UNDP, Implications of the COVID-19 Pandemic for Global Sustainable Finance: An Initial Framework for Response Strategies produced for the International Network of Financial Centres for Sustainability (FC4S Network) (United Nations Environment Programme, April 2020) p. 7

${ }^{8}$ Five Foundations Commit $\$ 1.7+$ Billion to Nonprofit Organizations in Wake of Pandemic: Doris Duke Charitable Foundation, Ford Foundation, W.K. Kellogg Foundation, John D. \& Catherine T. MacArthur Foundation, Andrew W. Mellon Foundation $<$ https://www.macfound.org/press/press-releases/five-foundations-commit-18-billion-nonprofit-organizations-wake-pandemic/> accessed 11 August 2020 
systems and an essential threat to nonprofits. ${ }^{1}$ With lower economic activities, environmental nonprofits around the world are reporting smaller donations. ${ }^{2}$ In the age of COVID-19 Pandemic, nonprofits are seeing donations drop, doors close, and cash reserves dwindle. ${ }^{3}$ Many nonprofits organizations rely on events to bring in new members or donations crucial to keeping their operations running. Financial troubles worry these groups, who are spending more of their time figuring out how to maintain employee levels while also trying to carry out their organizations' environmental purposes. ${ }^{4}$ These financial strains are leaving environmental nonprofits unable to carry on with their work to promote environmental advocacy. ${ }^{5}$

The economic crisis owing to the COVID-19 Pandemic is already impacting the financial health and wellbeing of nonprofits. In the US alone, nonprofits employ over 10 percent of the private workforce or approximately 12.3 million people. According to a Nonprofits Finance Fund Survey in 2018, almost 75 percent of nonprofits do not have six months of cash reserves. The financial fallout of the COVID-19 Pandemic is being felt as nonprofits are experiencing postponed programming and revenue-generating events, threatened academic enrolments, cancelled artistic seasons, fewer grants from foundations given lower endowments, reduced corporate sponsorship, and prospects that government contracts are at risk due to shortfalls in government budgets. In the latest CAF America Survey, 73 percent of nonprofits say they have already seen a decrease in contributions. Half said they expect to see revenue declined by over 20 percent over the next year. In contrast, the requirement for services is expected to increase due to the COVID-19 Pandemic. Further, economics and fundraising professionals forecast that the fall in charitable giving will possibly be more significant compared to that of the Great Recession in 2008 and that recovery will probably take longer. ${ }^{6}$

According to a May 13, 2020 report from the Charities Aid Foundation of America, almost 95 percent of nonprofits worldwide say they have been negatively impacted by the COVID-19 Pandemic. A follow-up to a survey carried out in late March, the report, The Voices of Charities Facing COVID-19 Worldwide Vol. 2, found that 94.4 percent of eight hundred and eighty organizations in a hundred and twenty-two countries surveyed between April 30 and May 6, 2020, reported negative impacts from the global health COVID-19 Pandemic crisis. ${ }^{7}$ According to a report from the Unemployment Services Trust, nearly a third of US nonprofits have reduced headcount or suspended operations as a result of the COVID-19 Pandemic. ${ }^{8}$ Since the COVID-19 strike, donations have fallen for more than two-thirds of nonprofits organizations, and 10 percent have stopped operations, according to a recent survey by the Charities Aid Foundation of America. According to a recent study of nonprofits, a staggering 97 percent of respondents anticipate their funding to decline through the next 12 months as the struggling economy and social distancing hurt fundraising efforts. ${ }^{9}$

A study conducted in early April 2020 by Charity Navigator in partnership with Reuters News reported that most nonprofits are suffering financially, cutting down on their programmes and laid off staff due to the COVID19 Pandemic. ${ }^{10}$ Most environmental nonprofits have cancelled their fundraising events intended to raise revenue through donations. It is noteworthy that most environmental nonprofits depend on donations from fundraising programmes for their work. According to Earthwatch-an environmental nonprofit:

Earthwatch depends on donations-above and beyond what we raise from volunteers who participate in our expeditions-in order to deliver our global conservation mission. In fact,

${ }^{1}$ UNEP and UNDP, Implications of the COVID-19 Pandemic for Global Sustainable Finance, supra note 139; Five Foundations Commit \$1.7+ Billion, ibid.

${ }^{2}$ Degnarain, supra note 88; See Stephen Maldonado, How COVID-19 is Changing the Way Nonprofits Fundraise [Interview] $<$ https://www.vault.com/blogs/coronavirus/the-impact-of-covid-19-on-the-nonprofit-sect or> accessed 29 July 2020.

3 Steve Zimmerman, 'Reimagine Your Nonprofit to Survive the Crisis' Harvard Business Review (Online, 1 June 2020) $<$ https://hbr.org/2020/06/reimagine-your-nonprofit-to-survive-the-crisis > accessed 29 July 2020.

${ }^{4}$ London Gibson and Sarah Bowman, 'Environmental Groups Struggle to Maintain Funding, Momentum as COVID-19 Pandemic Continues' IndyStar (Online, 18 May 2020) <https://www.indystar.com/story/news/env ironment/2020/05/18/environmental-groups-struggle-covid-19pandemic-continues/51856420 02/> accessed 29 July 2020.

${ }^{5}$ See Coronavirus: Environmental Charities Brace for Long-Term Financial Turmoil <https://www.edie.net/n ews/11/Coronavirus-greencharities-braced-for-long-term-financial-turmoil-that-will-impact-climate-change-efforts/> accessed 29 July 2020

${ }^{6}$ Five Foundations Commit \$1.7+ Billion, supra note 140; See Mahima Kapoor, RBI Needs To Do ‘A Lot More’ Amid Covid-19 Crisis, Says JPMorgan's Jahangir Aziz <https://www.bloombergquint.com/rbi-monetary -policy/rbi-needs-to-do-a-lot-more-amid-covid-19-crisis-saysjpmorgans-jahangir-aziz $>$ accessed 5 August 2020; See FAQs: Our Social Bond/Ford Foundation $<$ https://www.fordfoundation.org/ideas/equals-change-blog /faqs-our-social-bond/> accessed 5 August 2020.

${ }^{7}$ Most Nonprofits Negatively Impacted by COVID-19, Survey Finds $<$ https://philanthropynewsdigest.org/new s/most-nonprofits-negativelyimpacted-by-covid-19-survey-finds $>$ accessed 29 July 2020.

${ }^{8}$ Nearly a Third of Nonprofits Have Cut Staff or Suspended Operations < https://philanthropynewsdigest.org/ news/nearly-a-third-ofnonprofits-have-cut-staff-or-suspended-operations $>$ accessed 29 July 2020; See 'COVID-19 Nonprofits Workforce Trends Report' Unemployment Services Trust Report, 7 May $2020<$ https:// www2.chooseust.org/2020/covid-19-report> accessed 29 July 2020.

${ }^{9}$ Danielle Kost, Nonprofits Hurt by COVID-19 Must Hoard Cash to Hold On (Harvard Business School Working Knowledge, 8 May 2020) $<$ https://hbswk.hbs.edu/item/nonprofits-hurt-by-covid-19-must-hoard-cash-to-hold-on> accessed 29 July 2020; See The Impact of COVID-19 on Large and Mid-Sized Nonprofits <https:// independentsector.org/resource/covid19-survey/> accessed 29 July 2020.

${ }^{10}$ Impact of the Pandemic \& Economic Shutdown on the Nonprofits Sector: Aggregate Data from a Survey of Rated Nonprofits Across Cause Areas, (Charity Navigator, 17 April 2020) <https://www.charitynavigator.org/i ndex.cfm?bay= content.view\&cpid=7900 $>$ accessed 29 July 2020. 
volunteer contributions provide only half of the total resources Earthwatch needs to sustain over 40 field research expeditions, a wide variety of educational programs, corporate sustainability trainings, and more each year. ${ }^{1}$

Also, environmental nonprofits' staffs are now facing the challenge of being unable to conduct their work internationally. These are challenges facing all non-governmental organizations (nonprofits) but may hit environmental groups notably stronger, given the global travel restrictions measures imposed by several countries as a result of the COVID-19 Pandemic. ${ }^{2}$

\subsection{Acute Challenges For The Waste Management Industry Caused By Rises In Volumes Of Unrecyclable Medical Waste}

The considerable rise in medical waste due to the COVID-19 Pandemic has already had tremendous impacts on the waste sector. ${ }^{3}$ The increasing spread of the COVID-19 Pandemic is posing significant challenges to the waste industry, putting authorities, and waste workers under considerable pressure. ${ }^{4}$ Medical care facilities have experienced an explosion in the use of particular types of medical supplies, which has caused a rapid increase in medical waste. These medical supplies include disposable gloves, surgical masks, face and nose masks, bottles of sanitizers, water-proof protective gowns, rubber boots, rubber apron, soiled-tissue papers, and other personal protective equipment (PPE). These medical supplies and PPEs are critical for those fighting the COVID-19 Pandemic but are also widely used by the public. While these medical supplies and PPE are shielding us from the spread of COVID-19 Pandemic, significant numbers are entering the natural environment-they are ending up on the streets, in the seas, and among wildlife, because they are not always disposed of properly. Thus, adding to the worldwide burden of waste to the waste management industry. ${ }^{5}$

Given that surgical masks are not supposed to be worn for more than one day, their disposal, along with that of empty hand sanitizer bottles, soiled-tissue papers, and other PPEs, is leading to a stalk of massive medical waste in the environment. In Hong Kong, for instance, which has been fighting the COVID-19 Pandemic since January 2020, medical waste has already started polluting the environment. ${ }^{6}$ Discarded face masks are piling up on Hong Kong's beaches and nature trails, with environmental groups warning that the waste is posing a massive threat to marine life and wildlife habitats. ${ }^{7}$ According to the WHO's health guidelines, used face masks and soiled tissues must be thrown only into lidded litter bins. Simultaneously, any medical gear used by affected patients and hospital staff must be sterilized and burnt at high temperatures in dedicated incinerators. Only modern incinerators operating at $850-1100^{\circ} \mathrm{C}$, with special gas-cleaning equipment, can burn these items by international emission standards. $^{8}$

Unfortunately, not all countries or regions can adequately deal with the sudden rise in medical waste generated due to the COVID-19 Pandemic. Take the case of Wuhan, for instance. The Chinese city which has been at the spotlight of the COVID-19 Pandemic and which is home to over 11 million people is accounted to have generated 200 tons of medical trash on a single day (February 24, 2020), four times the amount the city's only dedicated facility can incinerate per day. ${ }^{9}$ According to the Chinese Ministry of Ecology and Environment (MEE), the

\footnotetext{
${ }^{1}$ Earthwatch is an International Environmental Nonprofits Organization that connects People with Scientists Worldwide to Conduct Environmental Research and Empowers them with the Knowledge they need to Conserve the Planet. See Introducing: Earthwatch at Home $<$ https://earthwatch.org/> accessed 29 July 2020.

${ }^{2}$ Degnarain, supra note 88 .

${ }^{3}$ Municipal Waste Management and COVID-19 (Association of Cities and Regions for Sustainable Resource Management, 2020) $<$ https://www.acrplus.org/en/municipal-waste-management-covid-19> accessed 31 July 2020; See Keith Alverson, Healthcare Waste: What to do with it? (United Nations Environment Programme, 9 April 2020) < https://www.unenvir onment.org/news-and-stories/story/healthcarewaste-what-do-it> accessed 1 August 2020

${ }^{4}$ See ISWA, COVID-19 Response International Knowledge Sharing on Waste Management (International Solid Waste Association, 2020); See Coronavirus Update: Health Care Waste Management <https://www.green hospitals.net/health-care-waste-management-corona-virusupdate/?mc_cid=1946b0d c0e\&mc_eid=c68fdaa5a9> accessed 1 July 2020.

${ }^{5}$ See Implications of COVID-19 for the Environment and Sustainability, supra note 49; Nikolia Apostolou, Coronavirus Plastic Waste Polluting the Environment $<$ www.dw.com>coronavirus-plastic-waste-polluting-the ...> accessed 17 May 2020; See For Better or Worse, COVID-19 is Changing Our Environment <https://www. outlookindia.com/.../for-better-or-worse-covid-19-is-changin g-our-environment> accessed 17 May 2020; See 'Discarded Coronavirus Masks Clutter Hong Kong's Beaches, Trails' Hong Kong Reuters (Online, 12 March 2020) $<$ https://www.reuters.com/news/picture/discarded-coronavirus-masks-clutter-hong-iduskbn20z0pp> accessed 15 May 2020 ; See COVID-19 Emergency Preparedness and Response: WASH and Infection Prevention and Control in Health Care Facilities Guidance Note (UNICEF, 23 March 2020) p. 6; See COVID-19 Waste Management Factsheet: Introduction to COVID-19 Waste Management (United Nations Environmental Programme, 2020) <https://wedocs.unep.org/bitstream/handle/20.500.11822/32282/COVIDWM .pdf > accessed 31 July 2020; See WHO and UNICEF, Water, Sanitation, Hygiene, and Waste Management for the COVID-19 Virus: Interim Guidance (World Health Organization and United Nations Children's Fund, 23 April 2020) <https://apps.who.int/iris/handle/10665/331846> accessed 25 June 2020; See Waste Management an Essential Public Service in the Fight to Beat COVID-19<https://www.unenvironment.org/new s-and-stories/ pressrelease/waste-management-essential-public-service-fight-beat-covid-19> accessed 1 August 2020.

${ }^{6}$ Suchetana Mukhopadhyah, COVID-19: Unmasking the Environmental Impact $<$ https://earth. org/covid-19-unmasking-the-environmentalimpact $>$ accessed 18 May 2020.

${ }^{7}$ Discarded Coronavirus Masks Clutter Hong Kong's beaches, supra note 155.

${ }^{8}$ Mukhopadhyah, supra note 156

${ }^{9}$ Ibid.
} 
disposal capacity of Hubei Province, the epicentre of the COVID-19 outbreak, rose from 180 tonnes per day before the outbreak to 667.4 tonnes. The Chinese MEE noted further that as of March 21, 2020, China's medical waste disposal capacity had reached 6,066.8 tonnes per day, up from 4,902.8 tonnes each day before the COVID-19 epidemic outbreak. ${ }^{1}$

With the import restrictions emergence in export markets and quick declines in the availability of cargo transportation services, the COVID-19 Pandemic crisis has led to increased volumes of un-shippable agricultural and fishery commodities. Because this waste is left to decay, it has led to large quantities of organic waste. Several export-oriented producers produce quantities far too vast for output to be absorbed in local markets, and therefore organic waste levels have increased significantly. ${ }^{2}$ Local waste concerns have surfaced as lots of municipalities have suspended their recycling activities over fears of virus propagation in recycling centres. ${ }^{3}$ The 'reduce, reuse, and recycle' sustainable lifestyle mantra is chucked into the dustbin as institutions and governments churn out medical waste while reverting to use-once-and-dispose stance for fear of the COVID-19 virus spread. ${ }^{4}$ All these developments have created severe challenges for the waste management industry at a period when they are functioning with inadequate capacity as a result of the COVID-19 Pandemic. ${ }^{5}$

\section{COVID-19 PANDEMIC: A CALL TO STRIKE A BALANCE BETWEEN ECONOMIC GROWTH AND ENVIRONMENTAL PROTECTION}

The COVID-19 Pandemic that is presently ravaging the world has highlighted the importance of having a safe, clean, and sustainable natural environment ${ }^{6}$ and, thus, signifies an urgent call to strike a balance between economic growth and environmental protection. For instance, so long as the COVID-19 Pandemic keeps economic activities reduced, greenhouse gas emissions-a primary source of environmental degradation will remain relatively low. ${ }^{7}$ The current 2020 economic lockdowns designed to minimize the spread of COVID-19, temporarily pressed the pause button on environmental degradation, and the subsequent reductions in air pollution have been dramatic. Such tendencies remind us how a great deal our actions drive environmental quality and how poorly we have acted as stewards of our environment. In light of how powerfully COVID-19 responses appear to have slowed environmental degradation, an essential question is how we will act as humans afterwards. Just as the present Pandemic is motivating us to rethink several cultural institutions, we have a once-in-a-generation opportunity to rethink the way we grow back our economies in a manner that does not endanger the global environment as we have in recent decades. ${ }^{8}$

Claims that protecting the environment would collapse economies were not simply short-sighted, but as well counterproductive. It is environmental destruction that has crashed the world economy to a halt. This provides a golden opportunity to entrench environmental protection and restoration in our economic systems. ${ }^{9}$ The degradation of our planet is not just an environmental problem; it presents serious global economic risks too. Our economies, livelihoods, and wellbeing all rely on the environment, from the food we eat to controlling our climate, regulating disease, and as a place of recreation. Without the environment, there would be no life. COVID-19 is the environment sending us a message. In fact, it reads like SOS signals for the human enterprise, bringing into sharp focus the need to live within the planet's means. The environmental, health, and economic cost of failing to do so are disastrous. ${ }^{10}$ COVID-19 is clearly a wake-up call that we must start living within our environmental boundaries. ${ }^{11}$ Global businesses know at the moment that success is not possible without a healthy environment. Before coronavirus, the need to create more resilient economies and societies were clear, now it is inescapable. Healthy societies, resilient economies, and thriving businesses rely on the environment. ${ }^{12}$

It would be short-sighted to conclude, for example, that the sudden reduction in greenhouse gas emissions is a long-lasting environmental enhancement as emissions will most possibly rise to previous levels when economic

\footnotetext{
${ }^{1}$ China Disposes of 182,000 Tonnes of Medical Waste amid COVID-19 Outbreak <http://en.people.cn/n3/ 2020/0324/c90000-9671785.html> accessed 1 August 2020.

${ }^{2}$ Hamwey, supra note 31 .

${ }^{3}$ Ibid.

${ }^{4}$ Odogwu, supra note 31 .

${ }^{5}$ Hamwey, supra note 31 .

${ }^{6}$ Boyd, supra note 103 .

${ }^{7}$ Hamwey, supra note 31 .

${ }^{8}$ Kip Hodges and Jeremy Jackson, 'Pandemics and the Global Environment' Science Advances [2020] (6)(28), eabd1325 DOI: 10.1126/sciadv.abd1325

${ }^{9}$ André Hoffmann, 'The Planet after the Pandemic' The Jakarta Post (Online, 9 June 2020).

${ }^{10}$ Partha Dasgupta and Inger Anderson, 'Coronavirus Shows we Must Change our Economy to Recognise that Human Wealth depends on Nature's Health' Independent (Online, 5 June 2020); See Partha Dasgupta and Inger Anderson, Coronavirus is an 'SOS Signal for the Human Enterprise' The Guardian (Online, 5 June 2020); See Hoffmann, supra note 168.

11 Paul Polman, This is a Wake-up Call. We must live within our Planetary Boundaries to avoid Future Pandemics $<$ https://www.ethicalcorp.com/wake-call-we-must-live-within-our-planetary-boundaries-avoid-futur e-pandemics $>$ accessed 31 July 2020.

${ }^{12}$ Grethel Aguilar, IUCN Calls on Business to Put Nature at the Heart of Economic Recovery Plans, <https://w ww.iucn.org/news/businessand-biodiversity/202006/iucn-calls-business-put-nature-heart-economic-recovery-pl ans> accessed 15 June 2020.
} 
activities pick up as the crisis resolves. ${ }^{1}$ In other words, if, as we all hope, economies recover quickly from this disruption, carbon emissions will bounce back too. Emissions may grow even more rapidly if countries prioritize economic growth over environmental protection. ${ }^{2}$ After the global financial crisis of 2008, for example, global $\mathrm{CO}_{2}$ emissions from fossil fuel combustion and cement production grew by $5.9 \%$ in 2010 , more than offsetting the $1.4 \%$ decrease in $2009 .{ }^{3}$ Thus, while some see great hope for global efforts for environmental action, for example, action on climate change, in our response to COVID-19, others are of the view that reduction in emissions hasn't impacted the climate itself and that we shouldn't expect it to unless the decrease in emissions is sustained for several years into the future. ${ }^{4}$

As we start to recover from COVID-19, we will have to think about how to rebuild our world and the global economy. We should take this opportunity to direct our actions towards stronger environmental protection. Global environmental experts have been calling on our capability to change and embrace transformations to make our ways of life more sustainable for a long time. We can heed to this call by making many smart, sustainable investments to avert another outbreak. We also have to take climate action to avoid future pandemics. For instance, preventing deforestation-a root cause of climate change can help stem biodiversity loss as well as slow animal migrations that can increase the risk of infectious disease spread. The COVID-19 Pandemic will only have longterm environmental positive impacts if we choose to stop sacrificing the environment's health for profit, convenience, and consumption, and find sustainable ways to inhabit our world by fostering a balance between economic growth and environmental protection. ${ }^{5}$

COVID-19 Pandemic provides a golden opportunity to entrench environmental protection and restoration in our economic systems. ${ }^{6}$ We must refuse to give in to the temptation to re-institute a pattern of environmental destruction, and must instead 'reinvent'-turn this period of crisis into an opportunity to build a 21 st-century economy and society ${ }^{7}$ that takes the environment's true value into account. ${ }^{8}$ According to Olivier De Schutter, the UN Special Rapporteur on extreme poverty and human rights, we must shift away from a development model that puts economic growth first, while hoping to wipe out the environmental damages and to compensate for the social effects of enlarged inequalities after that. The model of growth itself should incorporate environmental sustainability and social justice from the start. ${ }^{9}$ It will help us to build the biggest industrial market of the century, as it has become today more advantageous to protect the environment than to destroy it. ${ }^{10}$ However, the global community can live sustainably and responsibly. The quick and sudden improvement of the Earth's air quality and substantial decrease in global air pollution, due to the COVID-19 Pandemic, is a reminder that by striking a balance between economic growth and environmental protection, we can live in harmony and have a positive impact on our environment. ${ }^{11}$

\section{CONCLUSION}

The COVID-19 Pandemic has had both positive and negative impacts on international environmental protection. To sustain the positive impacts and avoid the negative impacts brought about by the COVID-19 Pandemic on international environmental protection. The author recommends that global leaders should be more proactive and innovative by strengthening, incorporating, and implementing environmental protection measures that will have sustained practical effects on the environment. More specifically, the various countries of the world should maintain the reduction in global greenhouse gas emissions by transit to a low-carbon economy through the use of low-carbon technology in their industrial and transportation sectors. A low carbon economy, also known as lowfossil-fuel economy or decarbonised economy is an economy founded on low carbon power sources that thus has a minimum output of greenhouse gas emissions into the atmosphere. A transition to a low-carbon economy will

\footnotetext{
${ }^{1}$ Hamwey, supra note 31 .

${ }^{2}$ Ibid.

${ }^{3}$ Helen Montford, Responding to Coronavirus: Low-Carbon Investments Can Help Economies Recover (World Resource Forum, 12 March 2020).

${ }^{4}$ Hurst, supra note 69; See Zeke Hausfather, COVID-19 could Result in much Larger CO2 Drop in 2020 (The Breakthrough Institute, 30 April 2020); See Fall in COVID-Linked Carbon Emissions won't halt Climate Change - UN Weather Agency Chief' UN News (Online, 22 April $2020)<\mathrm{https}: / /$ news.un.org/en/story/2020/04/ 1062332> accessed 20 August 2020.

${ }^{5}$ Schuijers, supra note 72; See RSTV: The Big Picture-Coronavirus Impact on Environment $<$ www.insightson india.com2020 /05/01/>rstv-thebig-pic...> accessed 6 June 2020 .

${ }^{6}$ Hoffmann, supra note 168

${ }^{7}$ Edward Cameron, A World made New: Beyond COVID-19 to a Low-Carbon, Resilient and Inclusive World, (Universal Rights Group: Geneva, May 13 2020) <https://www.universal-rights.org/blog/a-world-made-new-beyond-covid-19-to-a-low-carbon-resilient-and-inclusiveworld/> accessed 31 July 2020

${ }^{8}$ Editorial, (12 May 2020) 'Include the True Value of Nature when Rebuilding Economies after Coronavirus' Nature [2020] 581, 119, Doi: $10.1038 / \mathrm{d} 41586-020-01390-\mathrm{w}$

${ }^{9}$ Olivier De Schutter, COVID-19 Crisis Highlights Urgent Need to Transform Global Economy, Says New UN Poverty Expert (United Nations Human Rights Office of the High Commissioner, May 1, 2020).

${ }^{10}$ Bertrand Piccard and Frans Timmermans, Which World do we want after COVID-19? <https://www.euractiv .com/section/energyenvironment/opinion/which-world-do-we-want-after-covid-19/> accessed 31 July 2020.

${ }^{11}$ Fares, supra note 84 .
} 
also help to sustain the decrease in global air pollution and the improvement of the Earth's air quality.

More so, the unrestricted wildlife harvesting and trade might enhance the risks of emerging new viruses. Many scientists and environmental campaigners have been advocating and urging countries to ban illegal wildlife harvesting and trade. These actions would aid in protecting human lives from potential pandemics like COVID-19. In other words, it will help curtail the increasing interactions of humans and wildlife and the possibility of future pandemics through the transference of viruses from animals to humans. Therefore, considering environmental and public health, it is essential to ban illegal wildlife harvesting and trade globally.

Also, since the mismanagement and improper disposal of healthcare (medical) waste pose health risks to people and pollutes the environment, Nations should collect, treat and safely dispose of the increased volumes of medical waste generated due to the COVID-19 Pandemic using international best practices and standards. Finally, Nations should be discouraged from using the COVID-19 Pandemic as reasons to relax their environmental regulations and enforcement. Thus, there is a need for active and more potent national environmental regulatory surveillance by national environmental protection and enforcement bodies, national environmental nongovernmental organizations, and other environmental-related institutions. Further, Governments in countries experiencing increases in deforestation, illegal logging, mining, and poaching need to urgently resume and maintain environmental protection and enforcement efforts, notwithstanding the COVID-19 Pandemic. 